\title{
Behaviorally targeted location-based mobile marketing
}

\author{
Stefan F. Bernritter ${ }^{1}$ (D) Paul E. Ketelaar ${ }^{2}$. Francesca Sotgiu ${ }^{3}$
}

Received: 31 August 2019 / Accepted: 11 April 2021 / Published online: 21 June 2021

(C) The Author(s) 2021

\begin{abstract}
Marketers increasingly use behavioral targeting in location-based mobile marketing (LBMM). However, highly personalized marketing messages like this may backfire by eliciting consumer reactance. We suggest that LBMM efficacy depends on its potential to minimize consumer reactance, which can be achieved by effectively combining location targeting (in-store vs. outstore), behavioral targeting (based on consumers' product category involvement [PCI]), and the type of promotion offered (price vs. non-price promotion). Results of a field study, a virtual reality experiment, and two online experiments show that although instore mobile ads are generally more effective in increasing sales than out-store mobile ads, this is only the case if consumers have low PCI with the advertised product category, because this decreases their reactance. To attract consumers to stores by out-store LBMM, we show that firms should offer price promotions to consumers with low PCI and non-price promotions to consumers with high PCI, because these combinations of location targeting, behavioral targeting, and type of promotion elicit the least reactance and therefore result in a higher probability to buy.
\end{abstract}

Keywords Mobile marketing · Location-based advertising $\cdot$ Behavioral targeting $\cdot$ Reactance $\cdot$ Price promotions $\cdot$ Product category involvement

\section{Introduction}

Imagine that Robin is walking down Oxford Street and receives a push notification on her cell phone exclaiming, "Hi Robin! You are near Starbucks on Oxford Street. Currently there is $50 \%$ off on your favorite drink: Vanilla Latte!' How might Robin react? This is one of many examples of location-

Alina Sorescu and John Hulland served as Editors for this article.

Stefan F. Bernritter

stefan.bernritter@kcl.ac.uk

Paul E. Ketelaar

p.ketelaar@ru.nl

Francesca Sotgiu

F.Sotgiu@vu.nl

1 King's Business School, King's College London, Bush House, 30 Aldwych, London WC2B 4BG, UK

2 Department of Communication and Media, Behavioural Science Institute, Radboud University Nijmegen, PO Box 9104, 6500, HE Nijmegen, The Netherlands

3 Department of Marketing, School of Business \& Economics, Vrije Universiteit Amsterdam, De Boelelaan 1105, 1081, HV Amsterdam, The Netherlands based mobile marketing (LBMM) that consumers are being confronted with every day. The example above is based on an actual campaign by Starbucks (Econsultancy, 2016), and it illustrates that brands can choose from among a multitude of targeting options when employing LBMM campaigns. For example, they can target consumers inside or outside a store, on the basis of their previous consumption behavior, or deliver specific promotions (e.g., price or non-price promotions) to specific consumer segments. Although mobile ad spending is said to have accounted for $68 \%$ of all digital ad spending in 2020 (eMarketer, 2020), knowledge of how brands can use mobile technology to reach their customers effectively is limited and still evolving. According to some commentators, usage of location data is "one of the most misunderstood areas in marketing" (Czarny, 2018), with marketers still struggling to harness it effectively (Forbes Agency Council, 2017). Responding to recent calls for more research on personalization in mobile marketing (Tong et al., 2020), this current paper aims to extend our understanding of LBMM by investigating how LBMM can be combined with behavioral targeting to increase its efficacy.

LBMM is often delivered via push notifications by branded apps, such as those of Starbucks or H\&M. Interestingly, these apps are often integrated with the company's loyalty program, which allows marketers not only to observe consumers' exact 
real-time location via GPS but also to know their previous consumption behavior. This type of hyper-context information empowers marketers to develop more personalized marketing strategies that entail both location and behavioral targeting (Tong et al., 2020). Although personalization can have positive outcomes for marketers (Chung et al., 2016), an increasing body of research shows that it also has a high potential to backfire if consumers perceive advertising to be too personalized (Bleier \& Eisenbeiss, 2015a; White et al., 2008). Narrowly targeted ads often result in consumers feeling that their freedom of choice is being threatened and, as a consequence, behave contrary to the intentions of a marketing message - a process referred to as reactance (Fitzsimons \& Lehmann, 2004). Studies have increasingly called for further research on how brands should approach mobile marketing in ways that mitigate the negative effects of personalization while still providing consumers with added value (Grewal et al., 2016; Shankar et al., 2016). Given the damaging potential effects of reactance in highly targeted marketing communications (Tucker, 2014), such as behaviorally targeted LBMM, it is crucial for marketers to understand how different elements of a personalization strategy (e.g., location, behavior, and type of promotion) can be combined in a way that is less likely to elicit high levels of consumer reactance.

In the present research, we focus on how marketers should combine location targeting with behavioral targeting to generate successful LBMM campaigns that mitigate reactance in consumers. Specifically, we argue that the efficacy of mobile location targeting depends on consumers' previous consumption behavior. One of the most used behavioral factors informing behavioral targeting and message personalization strategies is consumers' product category involvement (PCI; Bleier \& Eisenbeiss, 2015a; Boerman et al., 2017). PCI is concerned with the personal relevance and importance of the product category to the needs and values of the consumer (Coulter et al., 2003; Zaichkowsky, 1986). PCI is not merely an attitudinal construct: Petty and Cacioppo (1981), for example, refer to involvement as the combination of motivation and ability, and Poiesz and de Bont (1995) define involvement as "momentary mobilisation of behavioral resources for the achievement of a personally relevant goal." A large body of marketing literature is dedicated to the important role of consumers' involvement. Research shows that PCI significantly affects consumers' behavioral and cognitive responses (cf., Coulter et al., 2003), such as attention, memory, satisfaction, opinion leadership, processing, search, brand commitment, and early adoption (for a review, see Laaksonen, 1994). PCI can easily be derived from consumers' previous browsing and/or shopping behavior. Deriving relevance for consumers based on their (or similar consumers') consumption behavior finds broad application in marketing in domains such as automated recommender systems (Häubl \& Murray, 2003; Häubl \& Trifts, 2000; Hennig-Thurau et al., 2012; Tsekouras et al.,
2020), retargeting, and personalized advertising (Bleier \& Eisenbeiss, 2015b; Lambrecht \& Tucker, 2013; Tucker, 2014). The majority of the LBMM literature focuses on consumers' location (Fong et al., 2015; Li et al., 2017) or the effects of different types of message frames in LBMM (Ketelaar et al., 2018; Li et al., 2017). However, to the best of our knowledge, empirical evidence on the interplay between mobile location targeting and behavioral targeting is still scarce. Bringing together location and behavioral targeting allows us to shed more light on how consumers respond to mobile marketing messages.

Broadly speaking, the two main streams of research in the LBMM literature are in-store and out-store LBMM. In-store LBMM research (Bues et al., 2017; Ketelaar et al., 2018) mainly investigates the effects of mobile messages and different location factors on consumers who are already in the store. Out-store LBMM (Dubé et al. 2017; Fang et al., 2015) is mainly concerned with the question of how location targeting on mobile phones can encourage consumers to visit a store. Importantly, because proximity to and presence in stores may indicate pre-existing interest, practitioners question whether LBMM leaves money on the table by targeting consumers who are already in the store and intend to purchase. ${ }^{1}$ This skepticism toward in-store LBMM is further fueled by the required investment in infrastructure (i.e., iBeacons) and much more effort required on the consumer side than for geofencing-based out-store LBMM; for in-store LBMM to work, consumers often need to install a company's app and have Bluetooth enabled. This situation has led to some commentators arguing that the adoption of beacon technology and in-store LBMM falls short of expectations (VentureBeat, 2018). A review of the literature indicates that these two LBMM approaches have been studied only in isolation. This does not allow us to answer when and how it is useful to employ in- or out-store LBMM. LBMM research on the effects of spatial proximity to an advertised product/service suggests that spatial proximity has a positive effect on conversion (Molitor et al., 2020). We extend this line of research by focusing on the contingencies of this effect. We demonstrate that, counterintuitively, in-store LBMM is often not more effective than out-store LBMM, and that its efficacy depends on consumers' PCI.

Moreover, the majority of LBMM research (Danaher et al., 2015; Dubé et al. 2017; Fang et al., 2015), as well as the industry, focuses on LBMM as a way to offer price promotions to consumers. A common assumption is that offering price promotions in the form of mobile coupons to customers near a store or product will result in higher redemption rates of the coupon. The efficacy of location-based mobile price promotions (via m-coupons) has mainly been investigated in comparison to no promotions (for an exception, see Molitor

\footnotetext{
${ }^{1}$ We thank an anonymous reviewer for this suggestion.
} 
et al., 2020). Price promotions are a relatively costly strategy, yet the comparison between the impact of ads offering discounts to consumers and ads that do not offer a discount via LBMM has not received much attention in the literature. This raises the question under which circumstances it is beneficial for brands to use LBMM to offer price discounts to consumers and under which circumstances discounts might be less effective. We show that price promotions have a direct effect on purchase behavior only for consumers with low PCI. For more highly involved consumers, brands can also benefit from nonprice promotions (i.e., promotions that inform consumers about products or services without offering them a monetary discount). Thus, both types of promotions can have beneficial effects, but only if they are targeted at the appropriate consumer segment. Not needing to rely exclusively on price promotions is important for a healthy brand (Ailawadi et al., 2003).

In this article, we follow the conceptual work of Grewal et al. (2016) and Hofacker et al. (2016) and suggest that the efficacy of LBMM depends on three important pillars: the location, the consumer, and the type of promotion offered. We aim to integrate these three pillars into a comprehensive consumer-centric framework of LBMM to provide marketers guidance on where, for whom, and which type of locationbased mobile ads should be employed. Specifically, we focus on whether marketers should (1) approach consumers on their mobile devices depending on their PCI inside or outside the store, and (2) use a price or a non-price promotion. In addition, we investigate the role of consumers' reactance as the underlying mechanism that mediates LBMM efficacy. We respond to calls for further scientific research on mobile marketing (Grewal et al., 2016; Shankar et al., 2016), on the role of customers in the evolving advertising landscape (Marketing Science Institute, 2020-2022), and on behavioral targeting in mobile marketing (Tong et al., 2020) through four studies: a field quasi-experiment, using a mobile loyalty app and database of a major European fashion retailer; a virtual reality lab experiment; and two online experiments.

The remainder of this article is structured as follows. We first review the relevant background literature and formulate hypotheses. We then report a quasi-experimental proof-ofconcept field study followed by three experimental studies that formally test our hypotheses. We close with a discussion of the theoretical and managerial implications of our work.

\section{Background and hypotheses development}

\section{Location, reactance, and $\mathrm{PCl}$}

Companies have long used location-specific information in their advertisements, from roadside billboards (e.g., "Turn right to Starbucks") to tailored online advertisements based on Internet Protocol addresses or Wi-Fi locations. The dynamic multimedia possibilities offered by mobile phones allow advertisers to adopt a more "geo-precise targeting" approach (Van't Riet et al., 2016). In contrast with locationbased (non-mobile) advertising, LBMM targets consumers (1) on the basis of their precise location based on GPS data, (2) individually on their personal mobile devices, and (3) in real time. ${ }^{2}$ These three factors result in greater advertising effectiveness (Van Doorn \& Hoekstra, 2013; Van't Riet et al., 2016) because they increase advertising relevance, attention, brand recall, and positive attitude toward the brand (Dahlén, 2005).

Mobile marketing literature indicates that the context in which consumers are exposed to mobile ads greatly influences their behavior. As summarized in the literature review in Table 1, most research in this domain tends to focus on broader contextual characteristics that affect all consumers present in a given location at the same time. For example, Li et al. (2017) show that mobile ads received on sunny days are generally more effective than ads received on rainy days. Andrews et al. (2015) find that consumers traveling in crowded subway trains are considerably more likely to respond to mobile offers than consumers traveling in less crowded trains. In a similar vein, Ghose, Kwon, et al. (2019a) find that consumers targeted via mobile transportation apps on their daily commute are more likely to redeem mobile coupons than non-commuters. Another stream of mobile marketing research is devoted to more targeted location-based advertisements. This line of work highlights the important role of spatial proximity to a product or store in LBMM efficacy. For example, Fang et al. (2015) show that consumers targeted with location-based mobile promotions in a geofenced area in proximity to a store purchased more than those who received the same offer at another location or received no offer but were within the same area. Similarly, in a longitudinal study, Danaher et al. (2015) show that spatial proximity to a store increases consumers' redemption rates of mobile coupons for that store. In addition, Bues et al. (2017) find that proximity to a product increases consumers' intention to buy a product offered via mobile price promotions. The positive effects of spatial proximity in mobile marketing research are attributed to factors such as increased goal relevance (Van't Riet et al., 2016), increased pleasure, arousal, and perceived value (Bues

\footnotetext{
${ }^{2}$ Online advertising (non-mobile) can also use location targeting in a rather rudimentary way. This is mostly based on IP address targeting, which allows brands to determine where consumers are approximately located. In terms of granularity, this type of targeting usually does not go further than targeting on the level of neighborhoods (more often cities or regions). What is different in LBMM is that consumers are being targeted based on their exact real-time location, based on GPS coordinates. Thus, while internet advertising could, for example, inform consumers that there is a new coffee shop somewhere in their district, LBMM could tell consumers that they are just few yards away from the next coffee shop (and potentially could navigate them to the store as well as offering them - based on their loyalty card data - a coupon for a product they like at the same time).
} 
Table 1 Overview of selected relevant LBMM literature

\begin{tabular}{lllllll}
\hline Study Method & Location & $\begin{array}{l}\text { Behavioral } \\
\text { targeting }\end{array}$ & $\begin{array}{c}\text { Behavioral } \\
\text { mechanisms } \\
\text { measured }\end{array}$ & $\begin{array}{l}\text { Type of } \\
\text { promotion }\end{array}$ & Setting & Summary
\end{tabular}

Bues et al., Experiment 2017

$\begin{aligned} \text { Danaher } & \text { Longitudinal field } \\ \text { et al., } & \text { study }\end{aligned}$

2015

Dubé et al. Field experiment 2017

Fang et al., Field experiment \& $2015 \quad$ surveys

Fong et al., Field experiment 2015

Ghose, Li, Field experiment

\& Liu,

$2019 b$

$\begin{array}{ccc}\text { In-store } \quad-\quad & \begin{array}{l}\text { Price \& } \\ \text { non-price } \\ \text { promotion }\end{array}\end{array}$

Out-store

$-$

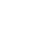

Price

Price

promotion
Out-store -

promotion

Snack food, menswear, shoes, electronics, hair care, gifts, homewares.

Movie theaters Movie theaters

Movie theaters promotion

Out-store

Price promotion

Movie theaters
Price promotion
Shopping mall
Ketelaa
et al.

2017

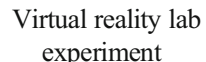

In-store

\section{location) \\ Out-store}

Location (the ad is received close to the product) is the most important value driver and increases customers' purchase intentions, while personalization (the ad is sent only to the participant) is the second most important, and price promotions (30\% discount vs. no discount) are least important. Customers' perceptions of value, pleasure and arousal and retailer dominance mediate the relationship between the value drivers and purchase intentions.

If a mobile coupon is delivered in the most convenient location (closer to the store offering the coupon), with a larger discount and a shorter expiry, it is more likely to be redeemed; a bundled offer leads to higher redemption rates than other price formats (percentage or dollar-amount discount).

Competition increases the profitability of behavioral targeting, where firms face symmetric pricing incentives that soften price competition. By contrast, competition lowers the profitability of geographic targeting, where firms face asymmetric pricing incentives that toughen price competition.

Location-based mobile promotions can increase contemporaneous sales and delayed purchases for 12 days after the mobile promotions. Perceived location and time congruence are significant factors driving sales, while planned buying factors have a significant impact on the delayed effect.

Competitive locational targeting is effective, while focal locational targeting produced decreasing returns to deep discounts, indicating saturation effects and profit cannibalization. Competitive locational targeting should be paired with deeper discounts to offset the locational switching costs incurred by the customer.

Trajectory-based mobile targeting (i.e., using traces of individual physical behavior) can be effective in increasing redemption probability. It is especially effective for high-income consumers and men but is less effective for consumers who like to explore across product categories. Promotions can inadvertently reduce impulse-purchasing behavior in an exploratory shopping stage.

In-store location-congruent ads lead to increased choice for the target brand compared with location-incongruent ads, regardless of the medium type (mobile or point-of-sales). In location-congruent settings, consumers' 
Table 1 (continued)

\begin{tabular}{lllllll}
\hline Study Method & Location & $\begin{array}{l}\text { Behavioral } \\
\text { targeting }\end{array}$ & $\begin{array}{l}\text { Behavioral } \\
\text { mechanisms } \\
\text { measured }\end{array}$ & $\begin{array}{l}\text { Type of } \\
\text { promotion }\end{array}$ & Setting & Summary
\end{tabular}

\begin{tabular}{|c|c|c|c|c|c|c|c|}
\hline & & & & & & & $\begin{array}{l}\text { attention is not affected by the medium } \\
\text { type; however, in a location-incongruent } \\
\text { scenario, mobile can attract more ad at- } \\
\text { tention than point-of-sales display ads, } \\
\text { which helps explain the increased } \\
\text { choice of the advertised brand. }\end{array}$ \\
\hline $\begin{array}{l}\text { Luo et al., } \\
\quad 2014\end{array}$ & $\begin{array}{l}\text { Field experiment \& } \\
\quad \text { surveys }\end{array}$ & Out-store & - & $\checkmark$ & $\begin{array}{l}\text { Price } \\
\quad \text { promotion }\end{array}$ & Movie theaters & $\begin{array}{l}\text { Temporal targeting and geographic } \\
\text { targeting can both increase sales. } \\
\text { Consumers who received mobile } \\
\text { promotions close in time and location } \\
\text { formed a more concrete construals, } \\
\text { which in turn increased their } \\
\text { involvement and purchase intentions. }\end{array}$ \\
\hline $\begin{array}{l}\text { Molitor } \\
\text { et al., } \\
2020\end{array}$ & Field experiment & Out-store & - & - & $\begin{array}{l}\text { Price \& } \\
\quad \text { non-price } \\
\text { promotion }\end{array}$ & $\begin{array}{l}\text { Nationwide } \\
\text { cross service } \\
\text { coupon app }\end{array}$ & $\begin{array}{l}\text { Geographic proximity increases the } \\
\text { relevance and effectiveness of } \\
\text { location-based coupons for consumers. } \\
\text { The most effective interface design in- } \\
\text { cludes coupons that are sorted by } \\
\text { distance, while distance information per } \\
\text { se is less important when coupons are } \\
\text { sorted by distance. The opposite is true } \\
\text { when coupons are randomly sorted } \\
\text { (display rank sensitivity decreases, } \\
\text { while distance sensitivity increases). } \\
\text { Users are more likely to respond to } \\
\text { location-based coupons in rural or sub- } \\
\text { urban than in urban areas. }\end{array}$ \\
\hline This study & $\begin{array}{l}\text { Field quasi experiment, } \\
\text { virtual reality lab } \\
\text { experiment, \& } \\
\text { online experiments }\end{array}$ & $\begin{array}{l}\text { In-store \& } \\
\text { Out-sto- } \\
\text { re }\end{array}$ & $\checkmark$ & $\checkmark$ & $\begin{array}{l}\text { Price \& } \\
\quad \text { non-price } \\
\text { promotion }\end{array}$ & $\begin{array}{l}\text { Fashion } \\
\text { retailer; } \\
\text { grocery } \\
\text { retailer }\end{array}$ & $\begin{array}{l}\text { Consumers' previous consumption } \\
\text { behavior constitutes important boundary } \\
\text { conditions for the efficacy of } \\
\text { (location-based) mobile marketing } \\
\text { campaigns. While in-store mobile ads } \\
\text { are generally more effective than } \\
\text { out-store ads, this is only the case if } \\
\text { consumers have low involvement with } \\
\text { the advertised product category, because } \\
\text { this decreases their reactance. To attract } \\
\text { customers to their stores, firms should } \\
\text { offer price promotions to consumers } \\
\text { with low PCI and non-price promotions } \\
\text { to those with high PCI because these } \\
\text { combinations of location targeting, be- } \\
\text { havioral targeting, and type of promo- } \\
\text { tion elicit the least reactance. }\end{array}$ \\
\hline
\end{tabular}

et al., 2017), and increased attention to the ad (Ketelaar et al., 2017).

The efficacy of LBMM has also been attributed to consumers' close psychological distance to a target product or choice when they receive a location-based mobile ad (Luo et al., 2014). Psychological distance is one of the core constructs of construal level theory (Liberman \& Trope, 2008; Trope \& Liberman, 2010) and refers to how far or close consumers perceive a target object or choice to be from themselves at that precise moment. Consumers face a closer psychological distance when exposed to in-store rather than out- store LBMM. More specifically, for in-store LBMM, the advertised products are present at the moment of exposure (temporal) and close to the receiver, because the receiver is located in the store (spatial), which makes him or her more likely to buy the product (hypothetical). Luo et al. (2014) find that because of this close psychological distance, people form more concrete construals, which makes them more involved in the offer received via LBMM and therefore more likely to make a purchase.

In accordance with the closer psychological distance, in-store LBMM should be more effective than out-store 
LBMM (Luo et al., 2014). However, we argue that this positive effect is dependent on the level of consumers' PCI with the advertised product, because ads targeted at lower PCI consumers in close spatial proximity to a product (i.e., in the store) might have less potential to evoke consumer reactance compared with ads targeted at higher PCI consumers. What is noteworthy about behaviorally targeted LBMM is that it extends the boundaries of personalization by targeting consumers with ads that are based on both their exact current location via GPS and their previous consumption behavior. Consumers may feel that their freedom of choice is threatened if they perceive ads to be too personalized (White et al., 2008). This perceived threat can result in a psychological state known as reactance (Fitzsimons \& Lehmann, 2004). Consumers differ in their propensity to experience reactance and how they react in response to it (Cherulnik \& Citrin, 1974). When consumers experience reactance, they are less likely to comply with marketing goals and often behave counter to the intention of the initial persuasion attempt to restore their freedom of choice (Bertini \& Aydinli, 2020; Brehm, 1966; Brehm, 1989). Employing behaviorally targeted LBMM campaigns might thus carry significant risk of eliciting reactance in consumers.

Specifically, targeting high-PCI consumers on their mobiles with an ad while they are inside the store is a very narrow targeting strategy and carries the risk of alerting consumers to why they have received this particular ad, i.e., based on their current location, at that particular moment in time, and congruent with their previous consumption behavior, which they may perceive as a threat to their freedom of choice (White et al., 2008). Thus, while in-store LBMM can be more effective because of the closer psychological distance and concrete construals therein (Luo et al., 2014), this benefit might vanish if consumers perceive their freedom of choice to be limited by ads that are too personalized. In-store LBMM targeted at high-PCI consumers, therefore, should evoke more reactance and consequently lower sales than in-store LBMM targeted at low-PCI consumers. Thus:

H1: In-store LBMM leads to a higher probability to buy an advertised product than out-store LBMM, but only for low-PCI consumers.

H2: Consumers' reactance mediates the effect proposed in H1.

\section{Attracting consumers to the store: The interplay between promotion type and $\mathrm{PCI}$}

We theorize that in-store LBMM can be more effective than out-store LBMM, and it is thus important to consider how the efficacy of the latter can be increased. We argue that the interplay of behavioral targeting based on consumers' PCI and the types of promotional messages sent to them determines the efficacy of out-store LBMM campaigns.

Limited research has investigated the effects of message and promotion types of location-based mobile advertisements. Molitor et al. (2020) find that location-based mobile non-price out-store promotions are more effective in increasing coupon choice compared with price promotions. Bues et al. (2017) find price promotions to be more effective than non-price promotions in in-store LBMM. This suggests that there might be still undiscovered moderators at play that determine LBMM price promotion efficacy. In support of this idea, the literature indicates that location-based effects can interact with message framing in mobile ads. For example, Li et al. (2017) investigate the effects of weather-based mobile promotions and show that compared with a neutrally framed ad, a prevention-framed ad can decrease the positive effect of sunshine and weaken the negative effect of rainfall. Furthermore, Ketelaar et al. (2018) demonstrate that framing LBMM price promotions more openly (i.e., providing less assistance to consumers in interpreting a persuasive message) can increase the positive effects of spatial proximity in instore LBMM by decreasing negative effects of perceived intrusiveness of mobile ads. This initial evidence underscores the importance of investigating location, behavioral, and message effects together in mobile marketing.

Persuasive messages, such as LBMM, can contain abstraction cues (Katz \& Byrne, 2013). The concrete incentives that are part of price promotions are low-level abstraction cues, whereas more abstract non-price promotions that inform consumers about the existence of a product are high-level abstraction cues. Recent extensions of construal level theory (Katz \& Byrne, 2013) suggest that the congruency between psychological distance and message abstraction cues plays an important role in how consumers process persuasive messages. According to construal level theory (Liberman \& Trope, 2008), people process LBMM in a more detail-oriented and concrete manner than non-locationbased ads because of a closer psychological distance (spatial and hypothetical). This means that LBMM price promotions can generally be regarded as cue-congruent, whereas LBMM non-price promotions are cue-incongruent (Katz \& Byrne, 2013). Indeed, empirical studies have shown that in situations of low-level construals, consumers process messages containing concrete appeals more fluently (Fujita et al., 2008; Kim et al., 2008). We therefore predict a positive main effect of LBMM price (vs. non-price) promotions:

H3: Out-store LBMM campaigns using price promotions lead to a higher probability to buy an advertised product than non-price promotions.

However, we argue that this effect is dependent on consumers' PCI. Specifically, price promotions are more 
concrete incentives to buy than non-price promotions. Delivering a price promotion for a product to a consumer who is already highly involved with the product category is thus a narrower and more personalized way of targeting than merely informing these consumers about the existence of the product or offering the same discount to lower involved consumers. Consumers with high PCI might therefore perceive out-store LBMM price promotions as too personal and hence as limiting their perceived freedom of choice. The positive effects of cue congruency on the efficacy of LBMM out-store price promotions might therefore be diminished by an increase in reactance for these consumers (White et al., 2008). Following this logic, consumers with high PCI should be more responsive to non-price promotions because these are less concrete incentives and are therefore less likely to be perceived as limiting one's sense of freedom of choice.

Contrary to high PCI consumers, consumers with low PCI might be particularly responsive to out-store LBMM price promotions. Low PCI consumers might be less likely to perceive the price promotion as limiting their freedom of choice; because of their low PCI, for these consumers a price promotion is a less personalized offer than it is for high PCI consumers. Low PCI consumers should therefore experience lower levels of reactance to price promotions than high PCI consumers. Furthermore, following the reasoning underlying Hypothesis 3 , for these consumers the reduction in price might further reduce their hypothetical psychological distance, which might be necessary to convince them to enter the store and make a purchase. For these consumers, however, nonprice promotions might increase reactance and therefore decrease probability of buying the advertised product, because the benefits of a close hypothetical psychological distance as well as increased fluency of concrete message appeals cease to apply (Fujita et al., 2008; Katz \& Byrne, 2013; Kim et al., 2008). Thus:

H4: Consumers' product category involvement moderates the effect predicted in H3: price (non-price) out-store LBMM promotions increase consumers' probability to buy an advertised product if they have low (high) PCI.

H5: Consumers' reactance mediates the effect proposed in H4.

\section{Overview of studies}

We conducted a proof-of-concept field study, a virtual reality lab experiment, and two online experiments (see Table 2). Using a field quasi-experiment, our proof-ofconcept study examines how consumers' probability to buy the advertised product category differs between consumers who have been exposed to in-store LBMM compared with consumers who have been exposed to out-store LBMM and whether these differences depend on consumers' PCI with the advertised product. Study 1 formally tests Hypothesis 1 and replicates the findings of the proof-of-concept study in a virtual reality lab experiment and further tests whether consumers' perceived reactance mediates the effect of LBMM location and PCI on consumers' probability to buy (H2). Study 2, an online experiment, replicates the findings of the previous studies. It further introduces additional measures to demonstrate the robustness of our effects. Study 3, also an online experiment, investigates the effects of price (vs. non-price) promotions in out-store LBMM on consumers' probability to buy the advertised product (H3). It also examines the moderating role of consumers' PCI in this context (H4). It further investigates whether consumer reactance mediates the effect of the type of promotion offered and PCI and probability to buy (H5). Figure 1 depicts our conceptual framework.

\section{Proof-of-concept study}

Before formally testing our hypotheses, this study explores the interplay between location targeting and behavioral targeting in the field. Specifically, we use this preliminary study to demonstrate that consumers' $\mathrm{PCI}$ moderates the effects of the location at which consumers are targeted on their probability to buy the advertised product category.

\section{Data, design, and participants}

Using the mobile application of a major European fashion retailer, we conducted a quasi-experimental field study with a single factor (location: out-store vs. instore) between-subjects design. The mobile application (available for Android and iOS devices) includes the retailer's loyalty program, e-commerce platform, and a push message function. This allowed us to send ads to actual consumers and to track their current and previous purchases and their location. It is important to note that this retailer carries only one (their own) brand. We targeted consumers who had installed the retailer's app and linked it with the retailer's loyalty program. In total, 3384 unique loyalty program card holders were part of this field study. Of these card holders, 3311 received the advertisement outside the store and 73 received the advertisement inside the store. The brand's privacy policy prohibited us from connecting the data with participants' demographics. 
Table 2 Overview of studies

\begin{tabular}{|c|c|c|c|c|c|c|c|}
\hline Study & $\begin{array}{l}\text { Dependent } \\
\text { Variable }\end{array}$ & $\begin{array}{l}\text { Location } \\
\text { LBMM }\end{array}$ & $\begin{array}{l}\text { Consumer's past } \\
\text { behavior }\end{array}$ & $\begin{array}{l}\text { Type of } \\
\text { promotion }\end{array}$ & Mediator & Setting & Hypotheses \\
\hline
\end{tabular}

\begin{tabular}{|c|c|c|c|c|}
\hline $\begin{array}{l}\text { Proof-of- } \\
\text { concept } \\
\mathrm{N}=3,384\end{array}$ & Probability to buy & $\begin{array}{l}\text { In-store vs out } \\
\text {-store }\end{array}$ & $\begin{array}{l}\text { Product category } \\
\text { involvement }\end{array}$ & $\begin{array}{l}\text { Field study - } \\
\text { Fashion retailer }\end{array}$ \\
\hline
\end{tabular}

\begin{tabular}{|c|c|c|c|c|c|c|}
\hline $\begin{array}{l}\text { Study } 1 \\
N=120\end{array}$ & Probability to buy & $\begin{array}{l}\text { In-store vs out } \\
\text {-store }\end{array}$ & $\begin{array}{l}\text { Product category } \\
\text { involvement }\end{array}$ & Reactance & $\begin{array}{l}\text { Virtual reality } \\
\text { experiment - } \\
\text { Supermarket }\end{array}$ & $\mathrm{H} 1, \mathrm{H} 2$ \\
\hline
\end{tabular}

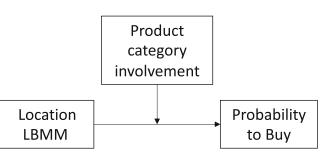

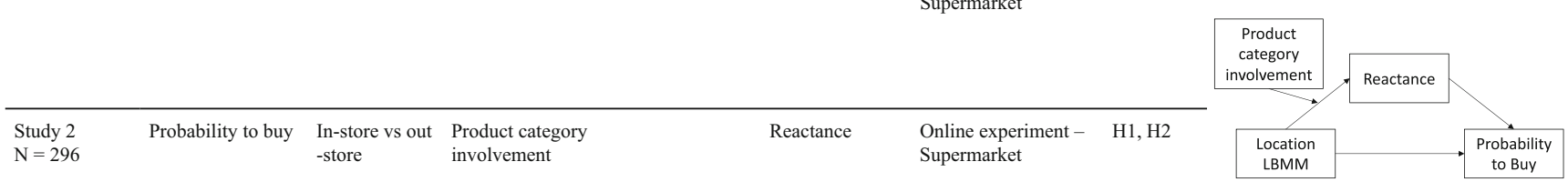

\begin{tabular}{|c|c|c|c|c|c|c|c|c|c|c|}
\hline \multirow[t]{2}{*}{$\begin{array}{l}\text { Study } 3 \\
\mathrm{~N}=293\end{array}$} & Probability to buy & Out-store & $\begin{array}{l}\text { Product category } \\
\text { involvement }\end{array}$ & $\begin{array}{l}\text { Price vs non- } \\
\text { price promotion }\end{array}$ & Reactance & $\begin{array}{l}\text { Online experiment - } \\
\text { Supermarket }\end{array}$ & $\mathrm{H} 3, \mathrm{H} 4, \mathrm{H} 5$ & $\begin{array}{c}\begin{array}{c}\text { Product } \\
\text { category } \\
\text { involvement }\end{array} \\
\end{array}$ & Reactance & \\
\hline & & & & & & & & $\begin{array}{c}\text { Type of } \\
\text { Promotion }\end{array}$ & & $\begin{array}{c}\text { Probability } \\
\text { to Buy }\end{array}$ \\
\hline
\end{tabular}

\section{Procedure}

We used geofencing to target consumers outside the store and iBeacons to target consumers inside the store. Geofencing is a virtual delimitation of a geographic area defined through Global Positioning and Wi-Fi-based Positioning Systems (Parise et al., 2016). For our study, we set a geofenced area with a radius of $100 \mathrm{~m}$ around every store. This radius is typically used by the retailer and is in line with developer recommendations (Google Developers, 2020). Consumers received a message when entering and staying in the geofenced area for longer than two minutes in order to avoid sending the message to users who were only passing the store by car or bike; even when passing multiple stores, consumers received the ad only once.

All of this retailer's stores are equipped with iBeacon sensors. These sensors are "devices equipped with Bluetooth technology to transmit data with other mobile devices and beacon sensors within a close proximity" (Parise et al., 2016 , p. 417). If consumers stayed within the range of the beacon for more than two minutes, they received the ad as a push notification on their mobile home screens; this was possible only if participants had activated Bluetooth. Again, even when visiting multiple stores, consumers received the advertisement only once. We required location services to be activated to receive the ads in both conditions.

Fig. 1 Conceptual framework

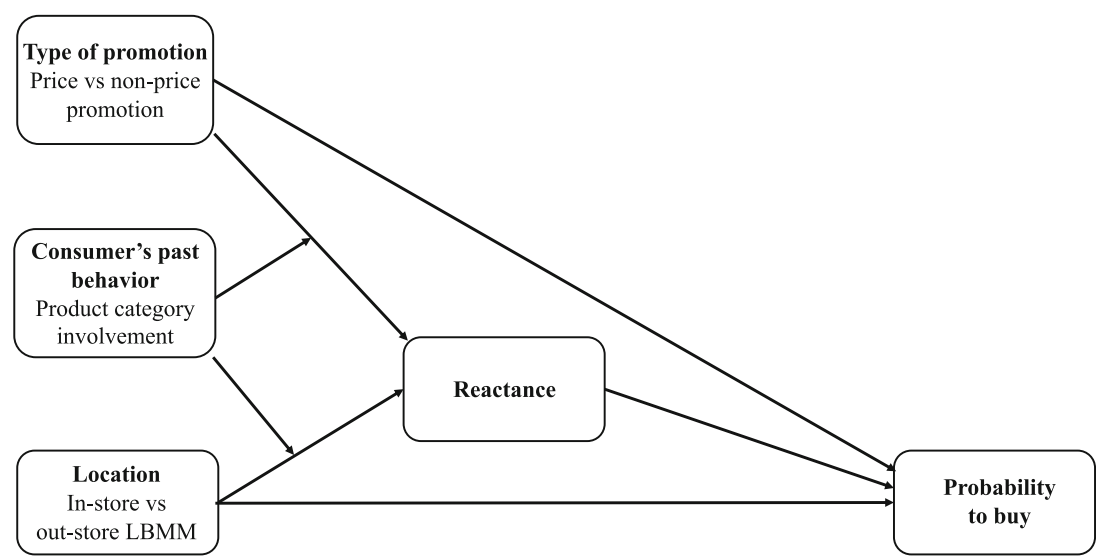


Because the retailer's application programming interface (API) did not allow us to implement proper randomization, we collected the data for both conditions in two separate consecutive weeks, from November 21, 2016 to December 2, 2016. In the first week, we ran the out-store ads via geofencing and ran the in-store ads via iBeacons in the second week. Targeting was set from Monday to Friday during the stores' opening hours. We ensured that consumers who received the ad in the first week did not receive it in the second week.

\section{Stimulus material}

Consumers in both conditions received the same on-screen push notification: "Baby it's cold outside! Get 30\% discount for 3 (name of items) and 20\% discount for 2." The content of this ad was based on the retailer's actual advertising strategy, aligned with its general marketing communication style. Onscreen push notifications were text only.

\section{Measurements}

$\mathrm{PCl}$ Because price is one of the most used indicators for involvement in the marketing literature (Hochstein et al., 2019; Laurent \& Kapferer, 1985; Rothschild, 1979), we operationalize product category involvement as the average price spent per item by a consumer for the advertised product category, computed by the total amount spent the year before, divided by number of items bought over the same time period $(\mathrm{M}=15.49, \mathrm{SD}=8.84)$.

Probability to buy the advertised product category We measure Probability to buy the advertised product as a dichotomous variable that assumes the value of 1 when consumers purchased the advertised product category, and 0 otherwise.
Control variables We control for location characteristics, such as the average income (in thousands) of consumers in the zip code area of the store $(M=27.16, S D=1.69)$, given that stores from wealthier areas may have a higher level of sales. We also include rainfall (in $\mathrm{mm})(\mathrm{M}=2.11, \mathrm{SD}=.26)$ to account for weather effects (Li et al., 2017). Finally, to account for differences in disposable income over time, we count the number of days until the end of the month $(\mathrm{M}=7.89, \mathrm{SD}=$ 2.54). For more descriptive statistics, see Table 3.

\section{Method}

To assess whether PCI plays a moderating role on the impact of LBMM on probability to buy, we ran a probit model. We recognize that customers already inside the store may be in a different state of mind than customers in the shopping district in proximity to the store. To decrease the bias, we use a propensity score matching approach to balance the samples and make the conditions as comparable as possible, accounting for the endogenous presence of the customers inside the store (Pearl, 2009). Web Appendix 1 and 2 report more details on the propensity score matching. The matched sample is based on 73 customers per condition. In the new out-store sample, 11 customers purchased the advertised product category (vs 14 in the in-store condition). On the new sample of matched customers $(N=146)$, we use a probit model to explain the probability to buy the advertised product category, using heteroskedasticity-consistent standard errors, and a logtransformation for the continuous variables that are not normally distributed.

\section{Results}

We report our results in Table 4 and Fig. 2. The results show that the purchase probability is higher for in-store ads (by means of iBeacons) than out-store ads (by means of

Table 3 Proof of concept study: Descriptive statistics

\begin{tabular}{|c|c|c|c|c|c|c|c|c|c|c|c|c|c|c|}
\hline \multirow[t]{3}{*}{ Variable } & \multirow{2}{*}{\multicolumn{2}{|c|}{ Overall Sample }} & \multicolumn{6}{|c|}{ Out-store } & \multicolumn{6}{|c|}{ Instore } \\
\hline & & & \multicolumn{2}{|c|}{ Overall } & \multicolumn{2}{|c|}{ No Purchase } & \multicolumn{2}{|c|}{ Purchase } & \multicolumn{2}{|c|}{ Overall } & \multicolumn{2}{|c|}{ No Purchase } & \multicolumn{2}{|c|}{ Purchase } \\
\hline & M & $\mathrm{SD}$ & M & $\mathrm{SD}$ & M & $\mathrm{SD}$ & M & $\mathrm{SD}$ & M & $\mathrm{SD}$ & M & $\mathrm{SD}$ & M & $\mathrm{SD}$ \\
\hline PCI & 15.49 & 8.84 & 15.38 & 8.71 & 15.68 & 8.82 & 11.50 & 5.88 & 20.11 & 12.84 & 22.66 & 12.88 & 9.33 & 4.25 \\
\hline Average spend per shopping occasion & 19.01 & 12.11 & 18.50 & 9.61 & 18.53 & 9.71 & 18.21 & 8.16 & 41.92 & 45.90 & 49.52 & 48.01 & 9.91 & 4.47 \\
\hline Purchase frequency & 9.64 & 10.13 & 9.68 & 10.18 & 9.48 & 10.19 & 12.27 & 9.79 & 7.57 & 7.46 & 7.81 & 8.12 & 6.57 & 3.69 \\
\hline Sales Value & 3.12 & 18.59 & 2.93 & 18.28 & 0.00 & 0.00 & 45.73 & 36.94 & 11.44 & 28.37 & 0.00 & 0.00 & 59.65 & 36.90 \\
\hline $\mathrm{N}$ Days till the next paycheck & 7.89 & 2.54 & 7.73 & 1.10 & 7.74 & 1.11 & 7.68 & 1.00 & 9.78 & 12.82 & 11.76 & 13.53 & 1.43 & 0.65 \\
\hline Rain & 2.11 & 0.26 & 2.10 & 0.23 & 2.10 & 0.24 & 2.07 & 0.21 & 2.44 & 0.55 & 2.38 & 0.52 & 2.66 & 0.60 \\
\hline Zip-code Income & 27.16 & 1.69 & 27.15 & 1.69 & 27.14 & 1.67 & 27.26 & 1.91 & 27.96 & 2.76 & 27.76 & 2.54 & 28.78 & 3.54 \\
\hline $\mathrm{N}$ & 3384 & & 3311 & & 3074 & & 237 & & 73 & & 59 & & 14 & \\
\hline
\end{tabular}


Table 4 Proof of concept study: Impact of LBMM on the probability to buy the advertised product category

\begin{tabular}{lllll}
\hline & Coef. & SE & $z$ & $p$ \\
\hline In-store (ref=out-store) & 4.525 & 1.339 & 3.38 & 0.001 \\
PCI* & 0.461 & 0.267 & 1.72 & 0.085 \\
In-store x PCI* & -1.779 & 0.492 & -3.361 & 0.000 \\
Control variables & & & & \\
$\quad$ Days to paycheck & -0.076 & 0.014 & -5.37 & 0.000 \\
Income* & -1.818 & 1.192 & -1.53 & 0.127 \\
Rain & -0.314 & 0.434 & -0.72 & 0.470 \\
Constant & 5.244 & 4.173 & 1.26 & 0.209 \\
& N=146 & & \\
& $\mathrm{X}^{2} 40.51, \mathrm{p}<.001$ & & \\
& Pseudo R ${ }^{2}=.26$ & & \\
& Log Likelihood=-38.46 & \\
& Highest VIF $=4.24$ & & \\
&
\end{tabular}

Note: Probit model explaining the probability to buy the advertised product category $\left(B u y_{i}\right) . B u y_{i}$ is equal to 1 if $B u y_{i}^{*}>0$ and 0 otherwise, where Buy $_{i}^{*}=\beta_{0}+\beta_{1}$ In-store $_{i}+\beta_{2} \ln$ PCI $_{i}+\beta_{3}$ Instore*ln PCI ${ }_{i}+\beta_{4}$ Days to paycheck $_{i}+\beta_{5} \ln$ Income $_{i}+\beta_{6}$ Rain $_{i}+\varepsilon_{i}$, with $\varepsilon_{i} \sim \mathrm{N}(0,1), i$ refers to customer $i$ (with $i=1, \ldots, I$ ). PCI is operationalized as the average price per item typically spent by the customer for the advertised product category. To better compare the instore to the out-store purchase behavior, we match the 73 customers inside the store with 73 customers outside the store with a similar purchase patterns using a propensity score nearest neighbor (one-to-one) matching approach (for details on the propensity score matching see Web Appendix 1-4). * Log-transformed variables

geofencing) $(\mathrm{b}=4.53, p=.001)$. We find that this relationship is moderated by PCI $(\mathrm{b}=-1.78, p<.001)^{3}$ : when consumers are not highly involved with the advertised product category, consumers who are exposed to an in-store ad are more likely to purchase the advertised product category compared with consumers who are exposed to an out-store ad. Furthermore, consumers who are highly involved with the advertised product category are more likely to purchase the advertised product category if exposed to an out-store ad compared with those exposed to an in-store ad (contrast for $\ln$ PCI at 10th percentile: $\mathrm{b}=0.47, \mathrm{SE}=.15,95 \%$ confidence interval $(\mathrm{CI})[.17$, .78]; 25th percentile: $\mathrm{b}=0.22, \mathrm{SE}=0.07,95 \%$ CI $[-0.11$, $0.16]$; 50th percentile: $\mathrm{b}=-0.10, \mathrm{SE}=0.06,95 \%$ CI $[-0.22$, $0.01]$; 75 th percentile: $\mathrm{b}=-0.20, \mathrm{SE}=0.06,95 \%$ CI $[-0.32$, $-0.07]$; 90th percentile: $b=-0.26, \mathrm{SE}=0.07,95 \%$ CI $[-0.39$,

\footnotetext{
${ }^{3}$ As the sign and significance level of the interaction in a non-linear model may be different for different observations, we follow Norton, Wang and Ai (2004) and Ai and Norton (2003) and we identify for how many observations the interaction is negative and significant. We observe that for all observations the interaction is negative $(\min =-.69, \max =-.02)$, and significant in $79 \%$ of the cases ( $\mathrm{z}$ value: $\min =-8.44, \max =-.80$; the interaction is significant for 116 observations out of 146). The not significant interaction effects come from observations associated with a low purchase probability: $67 \%$ of the not significant observations are linked to a purchase probability lower than .05 (20 observations out of 30 ), $17 \%$ (5 observations) to a purchase probability between .10 and .20 , and the remaining $16 \%$ (5 observations) are linked to a purchase probability between .20 and .40 . Furthermore, in line with $\mathrm{Li}$ et al. (2017, p. 768), we focus on the marginal effects to interpret the results.
}

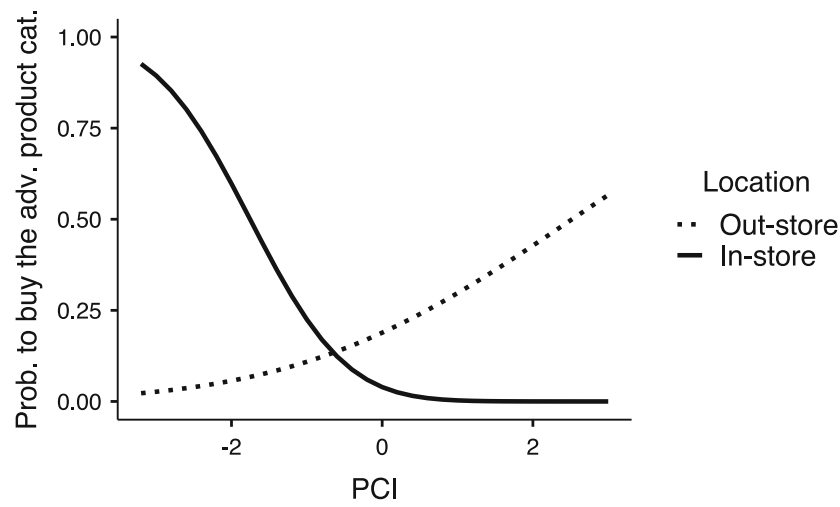

Fig. 2 Proof of Concept Study: Probability to buy the advertised product category as a function of LBMM Location and consumers' PCI (outstore $=$ geofencing; in-store $=$ iBeacons $)$

$-0.11])$. Finally, we find that the probability to buy the advertised product category is higher at the beginning of the month, when consumers have a higher disposable income after receiving their salaries $(b=-0.08, p<.001)$. Figure 2 reports the marginal effects that can be used to provide a descriptive interpretation of our results.

Robustness checks The moderating effect of PCI is also supported after excluding contextual variables from the analyses by using alternative operationalizations of PCI (e.g., average spend on the advertised product category, purchase frequency of the advertised product category). Our findings are also robust if running the model on the full sample, either without the propensity score matching or with a propensity score weighting approach. This also applies if we use sales of the advertised product category instead of the probability to buy the advertised product category as a dependent variable (see Appendix Table 11).

\section{Discussion}

This proof-of-concept study provides preliminary evidence that in-store LBMM is more effective than out-store LBMM when consumers are less involved with the advertised product category. These findings offer first empirical preliminary support for our framework, because they show that the effects of the location at which consumers are targeted with LBMM is dependent on behavioral factors (i.e., their PCI).

We acknowledge though that in this field quasi-experimental study several unobservable factors may bias our findings. For example, consumers who were targeted inside the store might be in a "shopping mindset," but also more likely to already have made the decision to purchase than consumers targeted outside of the store. Moreover, the time lag between the two quasiexperimental conditions may further bias our findings, as well as the fact that in-store LBMM is based on another type of technology (iBeacons) than out-store LBMM (geofencing). The different technology implies that customers need to have 
activated their Bluetooth connection, and this may be more likely for customers more technologically oriented (e.g., who may have Bluetooth enabled to use headsets or connect to their car or watch). The fact that many customers may not have their Bluetooth connection enabled might be a key driver of the imbalance in our sample between the in-store and the out-store condition. Hence, we conducted Study 1 to replicate the results of this proof-of-concept study in a controlled environment that allows us to formally test our hypotheses.

\section{Study 1}

Study 1 has three primary objectives. The first objective is to replicate the results of the proof-of-concept study in a controlled environment (same time window, same technology) with a different product category (wine in a supermarket). The second objective is to test consumers' reactance as the mechanism underlying the effects found in the proof-ofconcept study. The third objective is to rule out the potential effects of a self-selection bias in the proof-of-concept study.

To account for this, in the current study, we gave all customers a shopping task in order to elicit a shopping mindset with the plan of purchasing something. We conducted a highly controllable virtual reality supermarket (VRSM) experiment. A VRSM offers participants an immersive and interactive experience while enabling us to measure both actual brand choice and process variables (for more detailed information about this technology, please see Web Appendix 5). In this experiment we manipulated the location at which consumers received LBMM (inside or outside of the store) and the focal measurements of this study are consumers' PCI, consumer reactance, and whether they bought the advertised product.

\section{Participants and design}

Students of a western European university $(N=120 ; 61.7 \%$ female; $M_{\text {age }}=21.7$ years) participated in the study in exchange for financial compensation (€15). Participants were randomly assigned to one of the two conditions of a singlefactor between-subjects design (location: in-store vs. outstore), with probability to buy the advertised product as the dependent variable, PCI as the moderating variable, and reactance as the mediating variable.

\section{Procedure}

Upon arrival at the laboratory, participants were informed about the research procedure. They were told that they would engage in a grocery shopping task in a VRSM. Participants were given written information on a scenario in which they were having dinner with friends and had to buy their share of the groceries. The groceries they needed to buy were spaghetti, pasta sauce, and red wine. A particular brand of wine was the target brand in this experiment. The budget for these groceries was set at $€ 15$ to increase the salience of the promotion offered in the upcoming advertisement. After signing a consent form, participants entered the virtual reality lab where the experiment leader provided instructions on how to navigate the VRSM and place products in the shopping basket. Participants were warned of potential dizziness or nausea and told that they could stop the experiment at any time. They then put on HTC Vive headsets and held two Vive controllers in their hands (for an illustration, see Appendix 1, Fig. 6).

Participants sat in the passenger seat of a (virtual) car and were driven a short distance around the virtual town, with the virtual car trip ending in the parking lot of the supermarket. This activity helped the participants get used to the virtual environment without adding more difficulty through the requirement of additional controls, such as steering the car. The virtual supermarket was designed in such a way that participants could walk around the four-by-four meter space without accidentally bumping into real-life walls, while still being able to choose where they wanted to go. To go any further, participants needed to use their non-smartphone controller to be transported to a subsequent four-by-four-meter section of their choosing. In this way, participants were able to find the products on their grocery list. While shopping, participants could scan the desired product by pointing the smartphone at it and tapping the screen, thereby putting the product in their shopping basket and crossing it off their grocery list. When participants had put all the items they needed into their shopping basket, they could walk up to the checkout counter. Here, the simulation ended, and participants' product choice was registered. After they reached the cashier, the virtual reality screen went blank. Finally, participants filled out an electronic survey. The whole experiment took 30 to $45 \mathrm{~min}$.

\section{Manipulations}

During the experiment, all participants received the same ad for the wine brand La Tulipe de la Garde Merlot on their smartphones, but in different locations. Participants in the instore ad condition received the ad when they were in front of the wine aisle in the supermarket (for an illustration, see Appendix 1, Fig. 7), while those in the out-store ad condition received it in the car when they were on their way to the supermarket.

\section{Stimulus material}

We chose wine as a product because it is more of a highinvolvement product than other products found in a supermarket; it is relatively expensive and can only be judged when consumed (Chang \& Yen, 2013). Furthermore, consumers usually decide to buy wine before entering the store, although they generally tend not to inform themselves about specific 
wines before setting out to make a purchase. Instead, they base their decisions on available brands and in-store stimuli (Chaney, 2000).

Because existing brands add to the realism of the VRSM, we decided to have three real brands appear on the shelves. We pretested these brands for familiarity and consumers' brand attitude and found that they did not significantly differ in terms of these dimensions. The brands of wine chosen for the study were La Tulipe de la Garde Merlot (target brand), L'enclave Côtes du Rhône, and Wild Pig Syrah. Attitudes toward all three brands were neutral. Consequently, the probability that participants did not make a choice based on the reputation of, or preference for, a brand is high. For this experiment, we created an advertisement following the corporate identity of the supermarket on which the VRSM was based.

\section{Measures}

Reactance We measured consumers' reactance with a sevenpoint Likert scale ( 1 = "strongly disagree," 7 = "strongly agree") based on the study of Bleier and Eisenbeiss (2015a), who created the scale from two commonly used reactance scales (Edwards et al., 2002; Hong \& Faedda, 1996). The seven items were as follows: "This advertisement is disturbing," "This advertisement is interfering," "This advertisement is intrusive," "This advertisement is unwelcomed," "I want to resist the advertisement," "I want to dismiss the content of this advertisement," and "This advertisement is forced upon me." The resulting scale had high internal consistency $(\alpha=.82, \mathrm{M}=3.27, \mathrm{SD}=1.20)$.

PCI We used a scale from Pratt (2010) to measure participants' perceived involvement with wine. The seven items were as follows: "I am very interested in wine," "I find conversations about wine very enjoyable," "I wish to learn more about wine," "Deciding which wine to buy is an important decision," "I consider wine to be a central part of my lifestyle," "For me, drinking wine is a pleasurable experience," and "Wine is enjoyable to drink socially." The resulting scale had high internal consistency ( $\alpha=.93, \mathrm{M}=4.35, \mathrm{SD}=1.51)$. See Web Appendix 6 for an overview of the descriptive statistics. Although we measured PCI by means of past spend on the product category in the proof-of-concept study, we decided to use a scale that focuses more on the attitudinal dimension of involvement in this study for two reasons: first, participants in a lab experiment might have difficulty in accurately reporting their past spending, introducing reliability and validity issues. For example, self-estimated past spend might be biased by participants' product attitude, their socio-economic status, or social desirability. Using a validated scale to capture this construct allows us to circumvent this and has a long history in marketing research (Laurent \& Kapferer, 1985). Second, capturing the attitudinal dimension of PCI allows us to triangulate measurements and therefore confirm the patterns found in the proof-of-concept study that focused more on the behavioral dimension with a different validated measurement.

Probability to buy the advertised product Participants could choose their desired brand of wine by scanning the bottle with their virtual smartphone. At this point, they were still able to change their minds and choose another brand. When they arrived at the checkout counter, their final choice was registered, and we computed whether they chose the advertised product $(=1)$ or one of the competitors $(=0)$.

Privacy concerns To control for the possibility that consumers' privacy concerns bias our results, we measured this construct with a four-item 7-point Likert scale developed by Sheng et al. (2008). The scale had high internal consistency $(\alpha=.85, M=$ 4.10, $S D=1.35)$.

Ad and target product attention via eye-tracking We used attention toward the ad and the advertised product as a robustness check. These constructs were measured with an eyetracking device manufactured by SensoMotoric Instruments that was integrated into the HTC Vive goggles used for our study. The combination of eye-tracking and VR enabled us to calculate the gaze of participants in $3 \mathrm{D}$ space and observe what they were looking at during the experiment. Following Venkatraman et al. (2015), we defined the number of fixations of the eyes on the product and the advertisement as regions of interest in 3D space and as a proxy for attention. The sampling frequency of the eye tracker was $250 \mathrm{~Hz}$, with a frame rate of 90 frames per second, which is sufficient to capture the speed of eye motion.

\section{Results}

Our results show that $70 \%$ of the participants in the in-store condition chose for the advertised brand compared to $58 \%$ in the out-store condition. We predicted that consumers' reactance to the ads would mediate our prior finding that showing consumers location-based ads inside (vs. outside) the store increases purchasing, but only for low-PCI consumers. We tested this prediction using Hayes's (2013) PROCESS Model 7 (10,000 bootstrapped samples), with location $(0=$ out-store) as the predictor, perceived reactance as the mediator, consumers' PCI as the moderator, and probability to buy the advertised product as the dependent variable (Table 5).

The index of moderated mediation is significant (index $=$ $-.17, \mathrm{SE}=.09,95 \% \mathrm{CI}[-.45,-.03])$. Replicating our prior findings, conditional indirect effects analysis reveals that when consumers had low PCI with the advertised product (10th and 25th percentile), the indirect effect of location on brand choice through perceived reactance was positive and 
Table 5 Study 1: The mediating role of reactance on the probability to buy the advertised product

\begin{tabular}{|c|c|c|c|c|c|c|c|c|}
\hline \multirow[b]{2}{*}{ Antecedent } & \multicolumn{4}{|c|}{ Perceived Reactance } & \multicolumn{4}{|c|}{ Prob. to buy } \\
\hline & Coef. & SE & $\mathrm{t}$ & $p$ & Coef. & SE & Z & $p$ \\
\hline In-store & -1.55 & .65 & -2.37 & $<.001$ & .44 & .40 & 1.09 & .274 \\
\hline Reactance & - & - & - & - & -.49 & .17 & -2.93 & .003 \\
\hline PCI & -.42 & .10 & -4.40 & $<.001$ & - & - & - & - \\
\hline In-store $\times$ PCI & .34 & .14 & 2.41 & .018 & - & - & - & - \\
\hline Constant & $\begin{array}{l}5.20 \\
\mathrm{R}^{2}=.1 \\
\mathrm{~F}(3,11 \\
\mathrm{Log} \mathrm{Li} \\
N=120\end{array}$ & $\begin{array}{l}.42 \\
6)=6 \\
\text { kelih }\end{array}$ & $\begin{array}{l}12.32 \\
85, p< \\
\operatorname{ood}=11\end{array}$ & $\begin{array}{l}<.001 \\
.001 \\
.23\end{array}$ & 2.08 & .67 & 3.12 & .002 \\
\hline
\end{tabular}

significant (10th percentile: $\mathrm{b}=.45, \mathrm{SE}=.27,95 \%$ CI $[.05$, 1.23]; 25th percentile: $\mathrm{b}=.26, \mathrm{SE}=.18,95 \%$ CI [.0005, .73]). Conversely, when consumers had moderate to high PCI with the advertised product (50th, 75th, and 90th percentile), the indirect effect became negative and non-significant (50th percentile: $\mathrm{b}=-.008, \mathrm{SE}=.12,95 \% \mathrm{CI}[-.26, .24]$; 75 th percentile: $\mathrm{b}=-.18, \mathrm{SE}=.17,95 \%$ CI $[-.63, .05]$; 90th percentile: $\mathrm{b}=-.25, \mathrm{SE}=.20,95 \% \mathrm{CI}[-.82, .02])$. These results provide support for $\mathrm{H} 1$ and $\mathrm{H} 2$.

Robustness checks We include three additional covariates in our model to rule out two alternative explanations for our findings: First, to rule out the possibility that it was not reactance, but an increase in privacy concerns that elicited the effects observed, we include a privacy concerns measure in our model. Second, consumers in the out-store condition were passengers in a car when receiving the mobile ad. The LBMM literature suggests that commuting behaviors can alter mobile ad efficacy (Ghose et al., 2019a), which therefore might confound our findings from the out-store condition. Moreover, the different modes of movement might affect how much attention consumers spent on the ads. Hence, we include consumers' fixations on the ad and on the target product in our model. The results show that neither consumers' attention to the ad $(\mathrm{b}=-.69, p=.181)$ and the product $(\mathrm{b}=.04, p=.181)$, nor their privacy concerns $(\mathrm{b}=-.22, p=.189)$ had an effect on the likelihood that they would buy the advertised product. Furthermore, inclusion of these control variables in our moderated mediation model did not affect our results. We report the full model with these covariates in Web Appendix 7.

\section{Discussion}

The aim of this study was to replicate the findings of the previous study in a controlled but immersive virtual reality environment, offsetting the limitations of a field study and hence formally test our hypotheses. In addition, we were able to extend our insights into the mediating process at play by investigating the role of consumers' reactance in driving LBMM efficacy. The findings show that perceived reactance mediates the interaction effect of consumers' location and their PCI on their probability to buy the advertised product. In particular, we demonstrate that consumers experience the least reactance when they are targeted with instore mobile ads for products they are less involved with and, as such, are more likely to buy the advertised product. The results of this study support Hypotheses 1 and 2 and are aligned with the results we obtained from the field study. We further were able to demonstrate the robustness of our results by ruling out potential confounds by using eye-tracking technology.

There are two potential shortcomings of this study. First, in the out-store LBMM condition, participants were passengers in a (moving) car when receiving the ad. This movement might alter LBMM effects (Ghose et al., 2019a) and might therefore bias our results. Second, in this study as well as in the proof-of-concept study, we did not include a no- advertising baseline condition. Although these two studies allow us to estimate how inand out-store LBMM relate to each other and how this is affected by consumers' PCI, they do not allow us to draw conclusions about the efficacy of these targeting techniques in isolation, compared to exposure to no ads at all. The following study addresses these two points.

\section{Study 2}

This study has two primary objectives. The first objective is to replicate the findings of the previous two studies while taking into account a control condition in which consumers were not exposed to any advertising. The second objective is to further rule out the possible confound introduced by movement of the car in the previous study. Therefore, in Study 2, we manipulated out-store LBMM in a way that did not differ from the in-store LBMM condition in regard to how participants move. We manipulated the location at which consumers received LBMM (inside or outside of the store) and the focal measurements of this study were consumers' PCI, consumer reactance, and whether they bought the advertised product.

\section{Participants and design}

We recruited 306 students who were enrolled at a western European university to participate in an online experiment in exchange for partial course credit. They were randomly assigned to one of the three conditions of a single factor between-subjects design (location: in-store vs. out-store vs. no ad). Ten participants failed the attention checks and were excluded from the sample, leaving us with a final sample of 296 (32.4\% female; $M_{\text {age }}=$ 19.39; $\left.S D_{\text {age }}=1.53\right)$. 


\section{Procedure}

The procedure of this study is similar to that of Study 1 . We presented participants with a shopping scenario in which they were asked to imagine that they were on their way to their usual supermarket to buy groceries to host dinner with friends. As a first task, participants checked their grocery lists, which consisted of the following items: spaghetti, red wine (target category), Parmesan cheese, and tomato sauce. The scenario then described their journey to and through the supermarket. After entering the store, they first passed the shelves with pasta, then the shelves with the sauces, subsequently the cheese, and finally the wine section of the supermarket. At each step, they had to choose one out of four products to put into their shopping basket before proceeding to the next section. All products were presented in random order per category. We recorded which products they put into their shopping basket and then carried out measurements of the focal constructs of this study (PCI and reactance) after participants completed the shopping task.

\section{Manipulation}

We manipulated the location at which participants received the ad by either showing them an ad outside the store or inside the store, as described below. Participants in both LBMM conditions were shown the same ad (see Appendix 2, Figs. 8 and 9).

Out-store Participants got the following instruction when they reached the point in the scenario at which they were approaching the supermarket: "As you are approaching the supermarket, your phone vibrates, and you see a push notification of the app of the supermarket on your lock-screen. You open the notification and it shows you that currently the red wine Rapitala Nero D'Avola is on offer with $25 \%$ off."

In-store Participants got the following instruction when they reached the point in the scenario at which they were approaching the wine section of the supermarket: "On your way to the wine section of the supermarket, your phone vibrates, and you see a push notification of the app of the supermarket on your lock-screen. You open the notification and it shows you that currently the red wine Rapitala Nero D'Avola is on offer with $25 \%$ off."

\section{Measures}

We measured reactance $(\alpha=0.84, \mathrm{M}=3.16, \mathrm{SD}=1.07)$ and $P C I(\alpha=0.92, \mathrm{M}=4.09, \mathrm{SD}=1.46)$ in the same way as in Study 1. Probability to buy the advertised product was measured by observing which wine consumers purchased $(1=$ advertised brand; $0=$ one of the three other brands). See Web Appendix 8 and 9 for an overview of the descriptive statistics.

\section{Results}

We first estimate two probit models to show that the effects of LBMM (in- or out-store) differ from the no-advertising condition (Table 6). The first probit model has no ad as reference category and shows that both in- $(b=1.09, p<.001)$ and outstore LBMM $(b=0.68, p<.001)$ lead to a higher probability of choosing the advertised brand than under the no advertising condition. The second probit model has out-store LBMM as reference category and specifically shows our hypothesized in-store (vs. out-store) $\times \mathrm{PCI}$ interaction $(\mathrm{b}=-0.38, p=.006$; Fig. 3). Supporting H1, simple effects analysis shows that for

Table 6 Study 2: Impact of LBMM on the probability to buy the advertised product

\begin{tabular}{|c|c|c|c|c|c|c|c|c|}
\hline \multirow[b]{2}{*}{ Antecedent } & \multicolumn{4}{|c|}{ Model 1} & \multicolumn{4}{|c|}{ Model 2} \\
\hline & Coef. & SE & $\mathrm{z}$ & $p$ & Coef. & SE & $\mathrm{z}$ & $p$ \\
\hline Constant & 0.26 & 0.08 & 3.33 & $<.001$ & 0.26 & 0.08 & 3.33 & $<.001$ \\
\hline Out-store & 0.68 & 0.18 & 3.72 & $<.001$ & - & - & - & - \\
\hline In-store & 1.09 & 0.19 & 5.65 & $<.001$ & 0.41 & 0.20 & 2.09 & .037 \\
\hline No ad & - & - & - & - & -0.68 & 0.18 & -3.72 & $<.001$ \\
\hline PCI & 0.01 & 0.02 & 0.33 & .844 & 0.01 & 0.05 & 0.29 & .844 \\
\hline In-store $\times$ PCI & -0.22 & 0.13 & -1.65 & .099 & -0.38 & 0.14 & -2.73 & .006 \\
\hline No Ad $\times$ PCI & - & - & - & - & -0.17 & 0.13 & -1.31 & .190 \\
\hline Out-store $\times$ PCI & \multicolumn{4}{|c|}{$\begin{array}{l}\mathrm{R}^{2}=.10 \\
\text { Reference level }=\text { No ad } \\
\mathrm{X}^{2}=42.20, \mathrm{df}=5 ; \mathrm{p}<.001 \\
\text { Highest } \mathrm{VIF}=3.28 \\
N=296\end{array}$} & \multicolumn{4}{|c|}{$\begin{array}{l}\mathrm{R}^{2}=.10 \\
\text { Reference level=Out-store } \\
\mathrm{X}^{2}=42.20, \mathrm{df}=5 ; \mathrm{p}<.001 \\
\text { Highest } \mathrm{VIF}=3.28 \\
\mathrm{~N}=296\end{array}$} \\
\hline
\end{tabular}




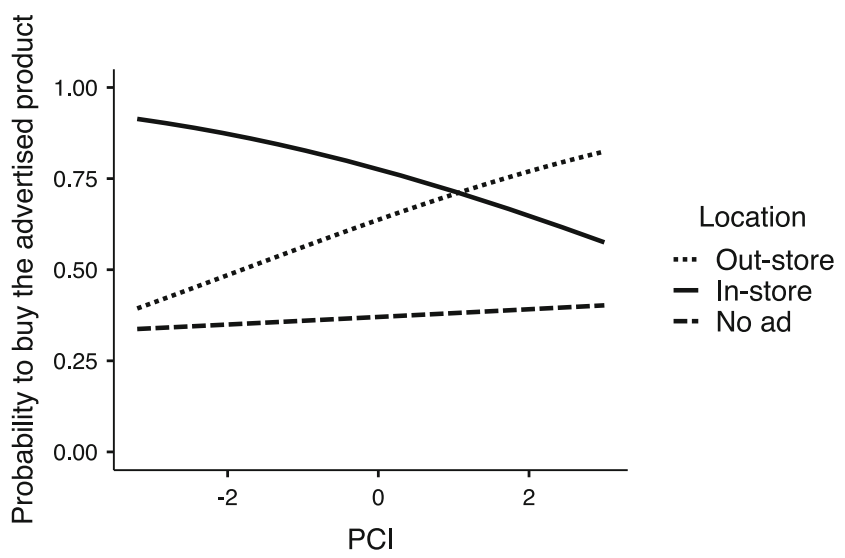

Fig. 3 Study 2: Probability to buy the advertised product as a function of LBMM Location and consumers' PCI

consumers who have low PCI (16th percentile), in-store LBMM leads to higher probability to buy (prob $=0.86$ ) than out-store LBMM (prob $=0.51, \mathrm{~b}=1.05, p<.001$ ). This difference becomes statistically non-significant for consumers with moderate $\left(50\right.$ th percentile; prob $_{\text {in-store }}=0.76$, prob $_{\text {out-store }}=$ $0.65, \mathrm{~b}=0.33, p=.087)$ and high PCI (84th percentile; probin-store $=0.68$, prob $\left._{\text {out-store }}=0.74, b=-0.16, p=.561\right)$. More details on the estimated marginal means are in Web Appendix 10.

Moderated mediation analysis We use Hayes's (2013) PROCESS Model 7 (10,000 bootstrapped samples), with location (in-store vs. out-store) as the predictor, perceived reactance as the mediator, consumers' PCI as the moderator, and probability to buy the advertised product as the dependent variable to test for moderated mediation effects on probability to buy the advertised product (Table 7). Supporting H2, the results show that the index of moderated mediation is significant (index $=-0.12, \mathrm{SE}=0.07,95 \%$ CI $[-0.30,-0.02]$ ). Conditional indirect effects analyses show that if PCI is low

Table 7 Study 2: Further evidence on the mediating role of reactance on the probability to buy the advertised product

\begin{tabular}{|c|c|c|c|c|c|c|c|c|}
\hline & \multicolumn{4}{|c|}{ Perceived Reactance } & \multicolumn{4}{|c|}{ Prob. to buy } \\
\hline & Coef. & SE & $\mathrm{t}$ & $p$ & Coef. & SE & $\mathrm{z}$ & $p$ \\
\hline Constant & 3.37 & 0.24 & 14.13 & $<.001$ & 1.56 & 0.72 & 2.16 & .030 \\
\hline In-store & -0.14 & 0.15 & -0.95 & .341 & 0.59 & 0.33 & 1.82 & .068 \\
\hline Reactance & - & - & - & - & -0.49 & 0.15 & -3.16 & .002 \\
\hline PCI & -0.46 & 0.17 & -2.67 & .008 & - & - & - & - \\
\hline \multirow[t]{2}{*}{ In-store $\times$ PCI } & 0.26 & 0.11 & 2.38 & .018 & - & - & - & - \\
\hline & \multicolumn{8}{|c|}{$\begin{array}{l}F(3,192)=2.78, p=.042 \\
\text { Log Likelihood }=14.77, \mathrm{p}<.001 \\
N=196\end{array}$} \\
\hline
\end{tabular}

(16th percentile; $b=0.28, \mathrm{SE}=0.16,95 \% \mathrm{CI}[0.04,0.66])$ instore (vs. out-store) LBMM has a positive effect on the probability to buy the advertised product. If $\mathrm{PCI}$ is moderate (50th percentile; $b=0.05$, SE 0.08 , 95\% CI $[-0.11,0.23]$ ) or high (84th percentile; $\mathrm{b}=-0.11, \mathrm{SE}=0.12,95 \%$ CI $[-0.41,0.08]$ ), however, the conditional indirect effects become statistically non-significant.

\section{Discussion}

The results of this study provide further support for our framework. We replicated the findings of the proof-ofconcept study and Study 1 while ruling out the alternative explanation that differences in the mode of movement between conditions might explain our effects. By including a baseline condition in our experimental design, we furthermore ruled out the possibility that our effects might not be driven by advertising.

Thus far we have presented three different studies, applying three different methodologies, that together provide consistent empirical evidence supporting our framework. We showed that consumers' PCI moderates the effects of in- versus out-store LBMM and that our effects were driven by consumers' reactance. A noteworthy finding is that in-store LBMM leads to a higher probability to buy the advertised product, particularly in consumers with low PCI. Because out-store LBMM is cheaper to implement and also has the advantage of being able to reach a much larger target audience than in-store LBMM, it is relevant to investigate ways to optimize out-store LBMM efficacy. In the following study we therefore set out to examine how different types of promotions delivered via out-store LBMM affect its efficacy and to what extent this depends on consumers' PCI.

\section{Study 3}

This study focuses on the difference between outstore LBMM price and non-price promotional messages and the extent to which their efficacy depends on consumers' PCI. While doing so, we investigate if consumers' reactance is the mechanism underlying these effects. In this experiment we manipulated the type of mobile promotion offered to consumers (price promotion or non-price promotion) and the focal measurements of this study are consumers' PCI, consumer reactance, and whether they bought the advertised product.

\section{Participants and design}

We recruited 303 UK consumers via Prolific $(70.6 \%$ female; $28.7 \%$ male; $0.7 \%$ non-binary; $M_{\text {age }}=33.80$; 


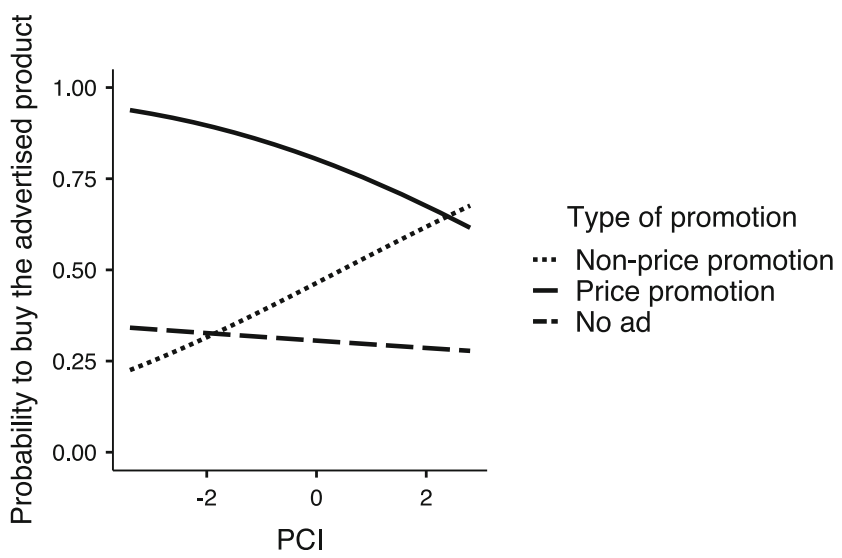

Fig. 4 Study 3: Probability to buy the advertised product as a function of the type of promotion offered and consumers' PCI

$\left.S D_{\text {age }}=11.90\right)$. They were randomly assigned to one of the three conditions of a single-factor between-subjects design (type of promotion: price promotion vs. nonprice promotion vs. no promotion).

\section{Procedure}

The procedure was very similar to that of Study 2. Participants were given the same shopping task within the same scenario. In the present study, all ads were out-store ads, which were received at the same moment as in Study 2 (in proximity to the store).

\section{Manipulation}

In the scenario, participants received either a mobile ad about the target brand with a $25 \%$ discount (price promotion condition), or the same ad without any discount (non-price promotion), or no ad at all (no ad condition). See Appendix 2 for examples of the stimuli.

\section{Measures}

We measured reactance ( $\alpha=0.94, \mathrm{M}=3.37, \mathrm{SD}=1.53), P C I$ $(\alpha=0.94, \mathrm{M}=4.24, \mathrm{SD}=1.49)$, probability to buy the advertised product in the same way as in Studies 1 and 2. Furthermore, we controlled for participants' age as well as their level of income to account for individual differences in sensitivity to price discounts. ${ }^{4}$ See Web Appendix 11 and 12 for the descriptive statistics.

\section{Results}

We first estimate a probit model to show that the effects of price and non-price promotion in LBMM differ from the noadvertising condition. The results in Table 8 show that both price $(\mathrm{b}=1.36 ; p<.001)$ and non-price promotions $(\mathrm{b}=0.42 ; p=$ $0.24)$ significantly increase the likelihood of choosing the advertised product. Specifically, $77.2 \%$ of consumers in the price promotion condition and $48.5 \%$ of those in the non-price promotion condition chose the advertised product, while only $31.7 \%$ in the

Table 8 Study 3: Impact of price vs. non-price promotions and PCI on the probability to buy the advertised product

\begin{tabular}{|c|c|c|c|c|c|c|c|c|}
\hline \multirow[b]{2}{*}{ Antecedent } & \multicolumn{4}{|c|}{ Model 1} & \multicolumn{4}{|c|}{ Model 2} \\
\hline & Coef. & SE & $\mathrm{z}$ & $p$ & Coef. & SE & $\mathrm{z}$ & $p$ \\
\hline Constant & 0.09 & 0.08 & 1.09 & .275 & 0.09 & 0.08 & 1.09 & .275 \\
\hline Price promotion & 1.36 & 0.20 & 6.74 & $<.001$ & 0.95 & 0.20 & 4.74 & $<.001$ \\
\hline Non-price promotion & 0.42 & 0.19 & 2.25 & .024 & - & - & - & - \\
\hline No ad & - & - & - & - & -0.42 & 0.19 & -2.25 & .024 \\
\hline PCI & -0.01 & 0.06 & 0.21 & .836 & -0.01 & 0.06 & 0.21 & .836 \\
\hline Price promotion $\times$ PCI & -0.17 & 0.14 & 0.84 & .204 & -0.40 & 0.14 & -2.82 & .005 \\
\hline Non-price promotion $\times$ PCI & 0.22 & 0.13 & 1.75 & .081 & - & - & - & - \\
\hline No Ad $\times$ PCI & - & - & - & - & -0.22 & 0.13 & -1.75 & .081 \\
\hline \multicolumn{9}{|l|}{ Control variables } \\
\hline Age & -0.03 & 0.01 & -3.64 & $<.001$ & -0.03 & 0.01 & -3.64 & $<.001$ \\
\hline \multirow[t]{2}{*}{ Income } & -0.06 & 0.03 & -1.93 & .054 & -0.06 & 0.03 & -1.93 & .054 \\
\hline & \multicolumn{4}{|c|}{$\begin{array}{c}\mathrm{R}^{2}=.17 \\
\text { Reference level }=\text { No ad } \\
\mathrm{X}^{2}=72.50 ; \mathrm{p}<.001 \\
\text { Highest VIF }=3.46\end{array}$} & \multicolumn{4}{|c|}{$\begin{array}{c}\mathrm{R}^{2}=.17 \\
\text { Reference level=Non-price promotion } \\
\mathrm{X}^{2}=72.50 ; \mathrm{p}<.001 \\
\text { Highest } \mathrm{VIF}=3.41\end{array}$} \\
\hline
\end{tabular}


no ad condition chose that product. We then estimate a second probit model with non-price promotion as reference category to be able to test our hypothesis pertaining the interaction between the type of promotion offered and PCI. This second probit model shows our hypothesized price promotion (vs. non-price promotion $) \times$ PCI interaction $(\mathrm{b}=-0.40, p=.005$; Fig. 4). Simple effects analysis shows that for consumers who have low PCI (16th percentile), price promotions lead to higher probability to buy (prob $=0.88$ ) than non-price promotions (prob $=0.34, \mathrm{~b}=1.61$, $p<.001)$. This difference stays statistically significant for consumers with moderate $\mathrm{PCI}$ (50th percentile; prob $_{\text {price promotion }}=$ 0.79 , prob $_{\text {non-price promotion }}=0.48, \mathrm{~b}=0.87, p=<.001$ ), but becomes statistically non-significant for consumers with high PCI (84th percentile; prob $_{\text {price promotion }}=0.70$, prob $_{\text {non-price promotion }}=$ $0.59, \mathrm{~b}=0.30, p=.279$ ). This partly supports Hypothesis 4 . More details on the estimated marginal means are in Web Appendix 13.

Moderated mediation analysis To test whether the interaction between the type of price promotion and consumers' PCI is mediated by consumers' reactance, we use Hayes's (2013) PROCESS Model 7 (10,000 bootstrapped samples), with type of promotion ( $1=$ price promotion) as the predictor, perceived reactance as the mediator, consumers' PCI as the moderator, and probability to buy the advertised product as the dependent variable and test for moderated mediation effects on probability to buy (Table 9). Supporting H5, the results show that the index of moderated mediation is significant (index $=-0.14, \mathrm{SE}=0.07,95 \%$ CI $[-0.31,-0.03]$ ). Conditional indirect effects analyses show that if PCI is low (16th percentile; $b=0.44, \mathrm{SE}=0.17,95 \%$ CI $[0.18$,
0.83]$,$) or moderate (50$ th percentile; $\mathrm{b}=0.18, \mathrm{SE}=0.09$, $95 \%$ CI [0.03, 0.38]), price (vs. non-price) promotions have an indirect positive effect on brand choice. If PCI is high (84th percentile), however, the effect becomes negative but statistically non-significant $(\mathrm{b}=-0.02$, $\mathrm{SE}=0.1395 \%$ CI $[-0.31,0.22])$.

\section{Discussion}

The results of this study provide evidence that while price promotions are more effective in increasing consumers' probability to buy the advertised product in general, this effect is dependent on consumers' PCI. We find that for low PCI consumers, price promotions are more effective than non-price promotions. Contrary to our expectations, we do not find a difference in response to price and non-price promotions for high PCI consumers. Hypothesis 4 is therefore only partially supported. For consumers with high levels of PCI, we do not observe a difference between price and non-price promotions, which makes nonprice promotions the more profitable type of promotion for this customer segment. Furthermore, we show that consumers with low and moderate levels of PCI experience lower levels of reactance if they are targeted outside the store with location-based price (vs. non-price) promotions and are therefore more likely to buy the advertised product.

\section{General discussion}

Brands can choose among a multitude of targeting options when employing LBMM campaigns. For

Table 9 Study 3: Results of the moderated mediation analysis

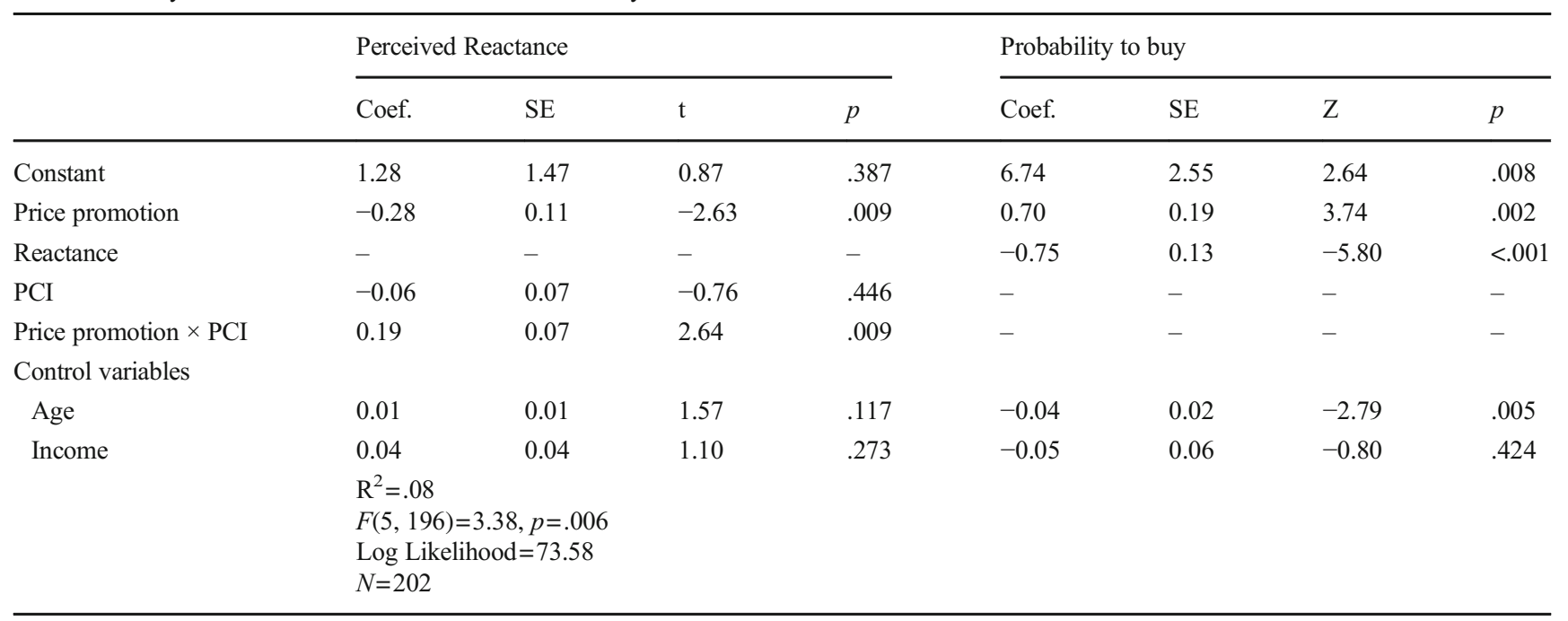


Table 10 Overview of the key findings

\begin{tabular}{|c|c|c|c|c|}
\hline Research question & Key finding & Theoretical support & $\begin{array}{l}\text { Empirical } \\
\text { support }\end{array}$ & Hypotheses \\
\hline $\begin{array}{l}\text { 1. Whom to advertise to } \\
\text { inside the store? }\end{array}$ & $\begin{array}{l}\text { Less involved } \\
\text { customers }\end{array}$ & $\begin{array}{l}\text { Construal level theory: closer psychological, } \\
\text { temporal and spatial distance instore and } \\
\text { more concrete construals (Luo et al., 2014). }\end{array}$ & Study 1,2 & H1 supported \\
\hline $\begin{array}{l}\text { 2. What is the underlying } \\
\text { mechanism? }\end{array}$ & $\begin{array}{l}\text { Reactance mediates } \\
\text { the } \\
\text { effect of LBMM on } \\
\text { the customer's } \\
\text { probability to buy }\end{array}$ & $\begin{array}{l}\text { Higher reactance for higher involved customers } \\
\text { inside the store (perception of too personalized ad; } \\
\text { White et al., 2008). }\end{array}$ & Study 1,2 & H2 supported \\
\hline $\begin{array}{l}\text { 3. How to attract } \\
\text { customers to the store? }\end{array}$ & $\begin{array}{l}\text { Price promotions for } \\
\text { less involved } \\
\text { customers. } \\
\text { Non-price promotions } \\
\text { and price } \\
\text { promotion } \\
\text { for more involved } \\
\text { customers }\end{array}$ & $\begin{array}{l}\text { Construal level theory: cue congruency and more } \\
\text { concrete appeals for price promotions. } \\
\text { Price promotions decrease hypothetical distance } \\
\text { for low PCI customers, but this is a very narrow } \\
\text { and personal way of targeting for high PCI customers. }\end{array}$ & Study 3 & $\begin{array}{l}\text { H3 supported } \\
\text { H4 partly } \\
\quad \text { supported }\end{array}$ \\
\hline $\begin{array}{l}\text { 4. What is the underlying } \\
\text { mechanism? }\end{array}$ & $\begin{array}{l}\text { Reactance mediates } \\
\text { the } \\
\text { effect of promotion } \\
\text { on the customer's } \\
\text { probability to buy }\end{array}$ & $\begin{array}{l}\text { Higher reactance for high PCI customers targeted } \\
\text { with price promotions because of narrow targeting. } \\
\text { Higher reactance for low PCI customers targeted } \\
\text { with non-price promotions, because increase in hypothetical dis- } \\
\text { tance and less concrete appeals (Katz \& Byrne, 2013) }\end{array}$ & Study 3 & H5 supported \\
\hline Overall take-aways: & $\begin{array}{l}\text { Customer involvement } \\
\text { customers' purchase } \\
\text { Reactance is the underl }\end{array}$ & $\begin{array}{l}\text { moderates the impact of location based mobile marketing on } \\
\text { decision. } \\
\text { ying mechanism. }\end{array}$ & & \\
\hline
\end{tabular}

example, they can target consumers inside or outside a store, target consumers on the basis of their previous consumption behavior, or deliver specific promotions (e.g., price or non-price promotions) to specific consumer segments. Given the complexity of these choices, it is not surprising that marketers have not yet been able to tap the full potential of LBMM. In this article, we set out to provide more insights into the workings and limits of LBMM by considering the effects of location, behavioral targeting based on consumers' PCI, and the type of promotion on LBMM efficacy. In particular, building on the preliminary evidence of a field study, with a virtual reality lab experiment, and two online experiments, we provide a consistent set of empirical evidence supporting our framework. We focus on the effectiveness of location-based mobile push notifications and address three questions related to the location, the consumer, and the type of promotion: (1) Where should marketers target consumers? (2) Which consumer segment to target (high

\section{Customer}

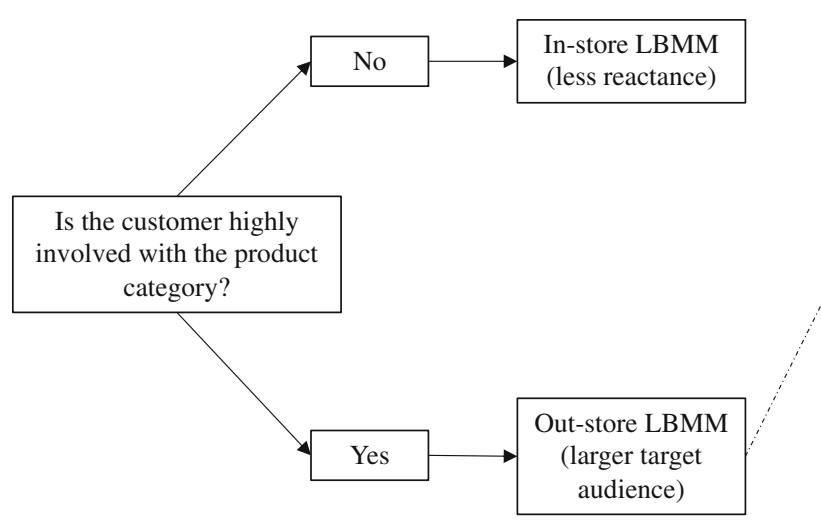

Type of promotion

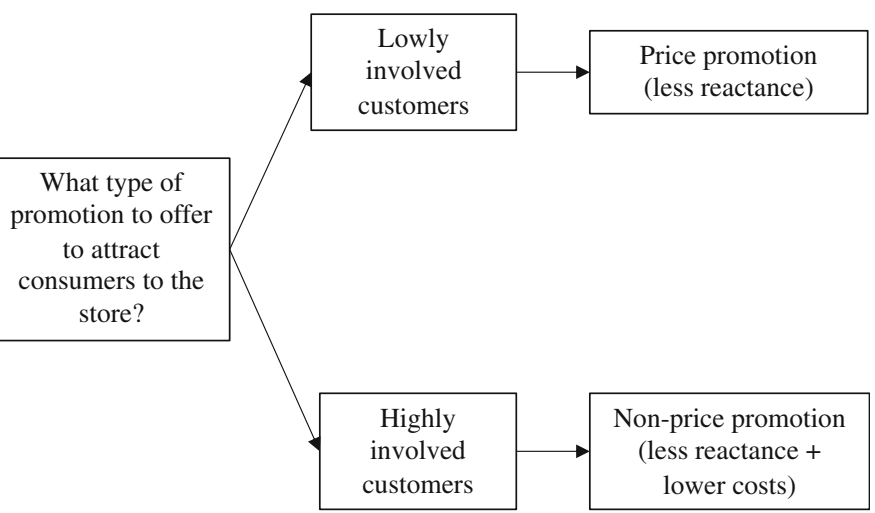

Fig. 5 Flow chart of the key managerial takeaways 
or low product category involvement)? And (3) Which type of promotion should brands offer to consumers?

\section{Considering the location, the consumer, and the type of promotion}

Where to target customers, outside or inside the store? We show that targeting consumers with LBMM inside the store is more effective than targeting them outside the store. Importantly, our findings show that consumers' previous consumption behavior constitutes an important boundary condition for this effect. Contrary to the popular belief that targeting consumers in proximity of a target product or store is more effective than targeting consumer farther away from the target (Fang et al., 2015), we show that in some situations, this is not the case.

Which consumer segment to target (high or low product category involvement)? Specifically, we demonstrate that in-store LBMM is more effective than out-store LBMM only for low PCI consumers. For high PCI consumers, we find no difference between in- and out-store LBMM. We also show that this effect is driven by a decrease in consumers' reactance when low PCI consumers are exposed to LBMM inside the store.

Which type of promotion to use? Although we find that instore LBMM is more effective than out-store LBMM in general, especially for low PCI consumers, we also investigated how marketers can use out-store LBMM most effectively to attract customers into the store. Specifically, we focused on whether out-store LBMM should be used as a means to provide consumers with discounts or, instead, to inform them about products or services without offering them a monetary discount. We show that location-based price (vs. non-price) promotions are more effective in increasing sales but that this effect is dependent on consumers' PCI. Specifically, less involved consumers are more likely to buy after exposure to location-based price promotions, while more involved consumers are equally likely to buy when confronted with location-based price or non-price promotions. Given the negative impact of price promotions on profitability and long-term brand equity, retailers may find non-price promotions a better alternative for more involved customers. For an overview of the key findings and takeaways, see Fig. 5 and Table 10.

\section{Theoretical contributions}

Taken together, the findings of all four studies consistently demonstrate that mobile location targeting should be understood as a function of both consumers' location and their consumption behavior to gain a more comprehensive understanding of how consumers will respond to mobile marketing messages. Our findings extend previous research on LBMM in multiple ways. To the best of our knowledge, we are among the first to compare in-store and out-store LBMM. Extending a large body of research that unequivocally demonstrates positive effects of proximity to a product (Fang et al., 2015; Luo et al., 2014), we identify consumers' PCI as an important boundary condition of this proximity effect. In doing so, we also suggest that proximity to a target product or store should not be equated to whether a consumer is located inside or outside a store. This underscores the importance of employing a more consumer-centric framework of LBMM. Although studies have combined location and behavioral targeting (Ghose, Li, \& Liu, 2019b), they have mainly inferred behavior from historical location data (e.g., where the consumers have been before). Our approach is unique in that it focuses on actual previous consumption behavior, thus allowing us to estimate consumers' (historical) relationship with the brand. Furthermore, we extend the recent work of Ghose, Li, and Liu (2019b) on trajectory-based mobile targeting; they argue that "location proximity alone is not sufficient for understanding and predicting consumers' physical behavior" (p. 20).

Consumers often perceive too much personalized advertising as a threat to their freedom of choice (Bleier \& Eisenbeiss, 2015a; White et al., 2008). We extend research in this stream of literature by showing that the interplay of location targeting, behavioral targeting, and the type of promotion offered considerably affects the extent to which ads evoke consumer reactance. Moreover, our study is one of the first to investigate location-based mobile non-price promotions and to compare them with location-based mobile price promotions. Although there is a strong focus on mobile price promotions in the LBMM literature (e.g., Dubé et al. 2017; Ghose, Li, \& Liu, 2019b), our findings show that mobile price promotions are not always more effective than non-price promotions. Considering that price promotions decrease retailers' margins and affect consumers' reference price (Mazumdar et al., 2005), price sensitivity, and brand image (Ataman et al., 2010), non-price promotions could be considered as a viable, more profitable, and brand building alternative for consumers with high PCI.

\section{Managerial implications}

Our findings suggest that managers should account for the consumption patterns of their customers before deciding on where and how to target them on their mobile devices. In-store LBMM is most effective if used as a channel to provide customers with price promotions for product categories they are less involved with. We showed a considerable increase in sales if LBMM is used in this way compared with both outstore and in-store LBMM for high PCI customers. Therefore, it might be worthwhile for firms to invest in in-store mobile targeting technology such as iBeacons to fully benefit from consumers' decreased reactance in this context. It must be noted, however, that in-store LBMM for highly involved 
customers has no effect on consumers' probability to make a purchase. Therefore, especially when targeting high PCI customers, it can be the more economical decision to invest in out-store LBMM and benefit from the larger target audience of possible recipients.

Another advantage of LBMM is that it enables brands to target consumers who are not in the store but in its general vicinity. Out-store LBMM is cheaper to implement and maintain than in-store LBMM. To take the most advantage of this technology to attract consumers to the store, we suggest that managers target more involved customers with non-price promotions. These high PCI consumers respond equally favorably to price and non-price promotions. It is therefore not necessary to offer price discounts to this consumer segment to attract them to the store. Conversely, managers should target less involved consumers with price promotions. For low PCI consumers a price promotion considerably increases the chance that they purchase the advertised product.

We also highlight the important role of consumers' reactance in the context of LBMM. Managers need to realize that using LBMM as a technique to target consumers carries a high risk of increasing consumer reactance. We show that the reason underlying the superiority of in-store LBMM in low-involvement contexts is that they evoke the least reactance among consumers. Before rolling out LBMM campaigns, managers should therefore consider campaigns' potential to evoke consumers reactance so as not to erode the future effectiveness of LBMM. Furthermore, for in-store LBMM targeted at high PCI customers, it might be worthwhile to consider using LBMM for mobile pull campaigns (i.e., offering discounts to consumers upon request) instead of using push notifications as done in the present studies (cf., Molitor et al., 2020). Because consumers who actively request promotions themselves should not experience any threat to their freedom of choice, the detrimental effects of reactance on purchase behavior should be resolved by relying on a pull approach. As such, push notifications could still be used for this customersegment butrather as a customer relationship management tool, for example, to welcome customers to the store, instead of sending them unsolicited ads via mobilepush.

\section{Limitations and future research directions}

As with any study, our studies have several limitations that future research might address. In our field study, we use the app and customer base of a fashion retailer. This means that consumers who installed the app and connected it with their loyalty card might naturally be more involved with the categories sold by the retailer (even if not with a given promoted category). Although this is not the case in our other studies, in which we replicate and extend the findings of the field study, wenote thatconsumers' PCI scores in the field study should be interpreted within the context of a relatively highly involved consumer segment.

Furthermore, this study is limited to the context of branded apps. The choice for this context was guided by the unique ability to connect behavioral and location data. It would be fruitful to extend the context of LBMM by examining other types of mobile advertising, such as in-app advertising or traditional mobile browser ads. In addition, we use previous purchase data for behavioral targeting. Because these data are not always obtainable for brands, research could extend the scope of LBMM to behavioral targeting based on other metrics, such as browsing and search history (Wang et al., 2019), or demographic targeting.

In Study 3, we did not compare in-store and out-store LBMM. Thus, it would be worthwhile to investigate whether the demonstrated patterns change if consumers are targeted inside the store. The recent Grewal et al. (2020) study implies that this indeed might be the case. The authors found that price (vs. non-price) promotional messages in in-store integrated mobile kiosks were more effective in increasing purchases of substitute products and that this effect was stronger for consumers who spend less money weekly. This finding suggests that the location (in-store vs. outstore) at which consumers are being targeted with mobile ads moderates the interaction between the type of price promotion and PCI. In addition, we limited our focus to comparing price and non-price promotional messages. As retailers implement a multiplicity of different types of promotional messages to ensure variety and to avoid lowering consumers' price perception and brand loyalty (Gedenk \& Neslin, 1999; Nunes \& Park, 2003), it would be relevant to investigate the efficacy of alternative nonmonetary promotions in LBMM (e.g., premiums, contests, sweepstakes, and samples) as well as message-framing effects (Ketelaar et al., 2018; Li et al., 2017).

We build upon the reactance literature that shows that too personalized ads can threaten consumers' perception of freedom of choice and therefore result in consumer reactance (Bleier \& Eisenbeiss, 2015a; White et al., 2008). This conceptualization of reactance is closest to the original reactance literature (Brehm, 1966; Brehm, 1989). However, the literature indicates that reactance may also be evoked by other factors that may be relevant in the context of LBMM. Examples are perceived intrusiveness of ads (Edwards et al., 2002) or perceived privacy invasion (Yost et al., 2019). These drivers of reactance might operate differently in other LBMM contexts and would therefore be worthwhile to investigate.

Although reactance, as the focal mechanism underlying our effects, is focused on sidestepping negative consequences of LBMM, reactance may not be the only relevant mechanism to study. In particular, itmaybeinteresting to furtherinvestigatemechanisms that positively affect LBMM efficacy. LBMM may, for example, trigger consumers' need for uniqueness (Stiglbauer \& Kovacs, 2019), which might increase its efficacy. Furthermore, through its highly personalized nature, LBMM might also enhance consumers' trust in the advertised brand (Komiak \& Benbasat, 2006). Another interesting avenue for future research might be to examine to what extent LBMMcan serve as an implied social label. Summers et al. (2016) have shown that behavioral targeting can result in consumers recognizing that the served ads are based on 
marketers' inferences about their identity and that consumers consequently adjust their self-perception to match these implied social labels. Given the even more personalized nature of LBMM, it is conceivable that this effect might be stronger in LBMM than in behavioral targeting alone.

Moreover, we did not consider competitive actions. Reactance may be triggered not only by the focal brand push notification but also by previous push notifications from neighboring stores. Scholars focusing on out-store promotional messages have argued that retailers should consider targeting consumers when they are visiting competitors (Fong et al., 2015). Dubé et al. (2017) recently extended those findings by demonstrating that the profits from this competitive locational targeting are reduced if the competitor also launches a targeting campaign. However, these studies focused on out-store messages. Future studies could also include both in-store and out-store push notifications (on top of the traditional marketing stimuli) to assess the short- and long-term implications of reactance and saturation. Research such as this could include a closer examination of the effects of the frequency of received LBMM promotions. Industry research suggests that if consumers receive more than a single promotion via Beacons per location visited, they are considerably more likely to stop using it and uninstall the app (MarketingDive, 2014). This is in line with our framework which is centered around reactance, because more frequent promotions could result in a higher sense of loss of freedom of choice. Therefore, it is important to investigate where the thresholds of such an effect lie and whether firms should potentially target consumers with both in-store and out-store LBMM consecutively.

\section{Appendix 1: Illustration stimuli and setup, Study 1}

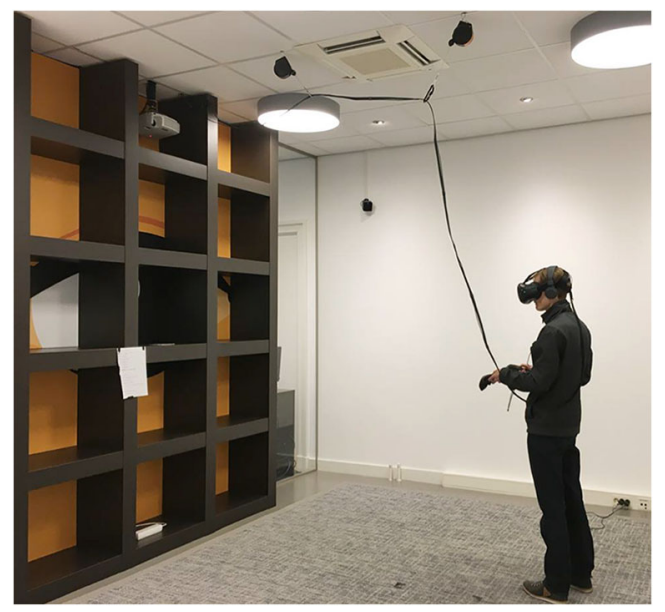

Fig. 6 Participant during the experiment

Fig. 7 Ad received in the store

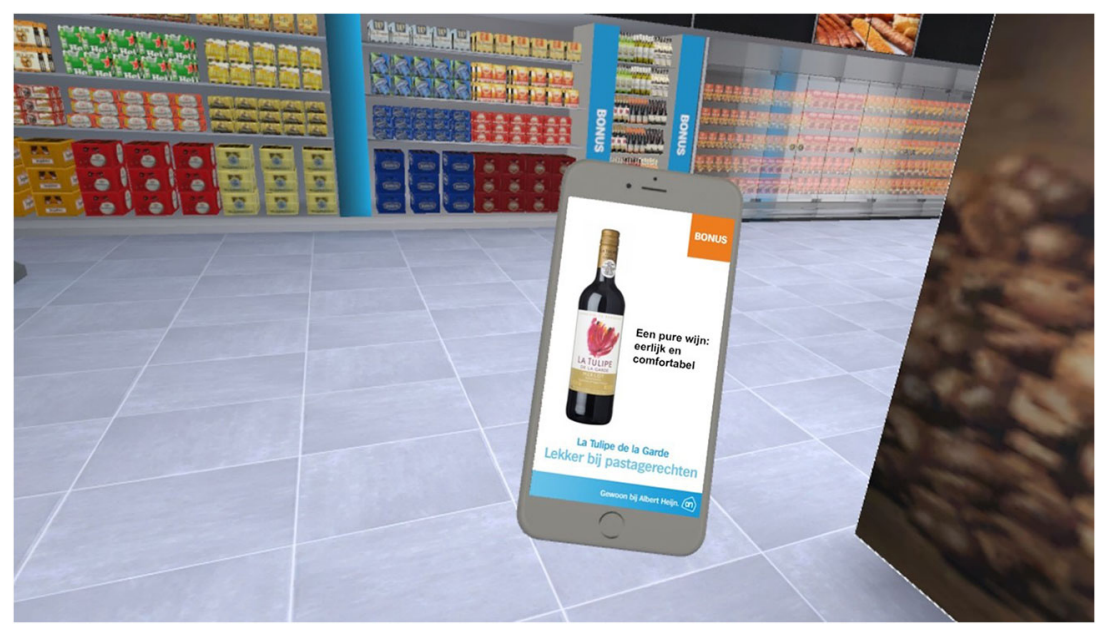




\section{Appendix 2: Illustration stimuli and setup,}

\section{Studies 2 and 3}

Fig. 8 Example product choice task Studies 2 \& 3

\begin{abstract}
You arrive at the shelves with the wine. You have the choice between the four items shown below.
Please select which item you would like to put into your shopping basket.
\end{abstract}

Barbaresco Riserva DOCG Terre da Vino

Moramari Montepulciano D’Abruzzo

Montepulciano La Piuma

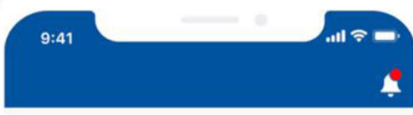

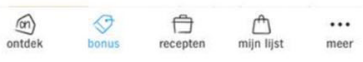

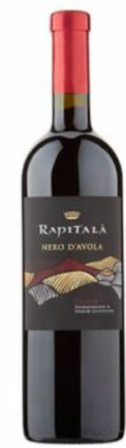

Rapitalà Nero D'Avola

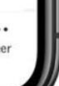

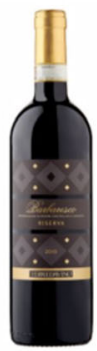

Rapitalà Nero D'Avola
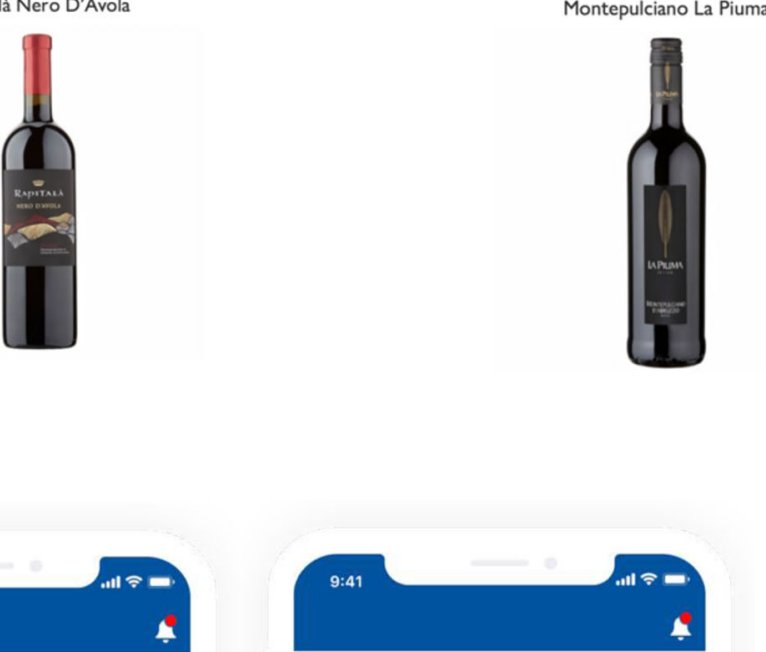

$$
\text { D'Avola }
$$

E $25 \%$ Off.

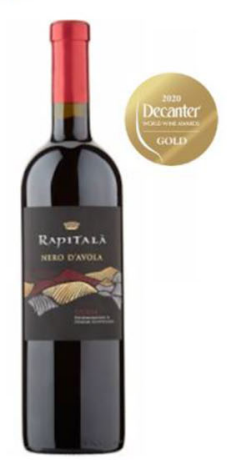

Rapitalà Nero

D'Avola

$\stackrel{\bigodot}{\equiv}$

Ð
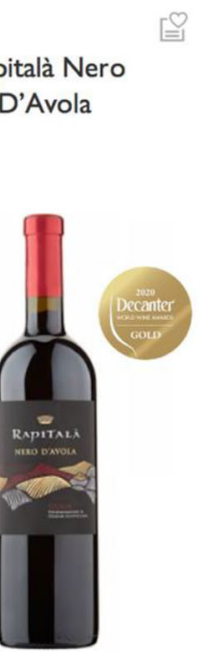

1.
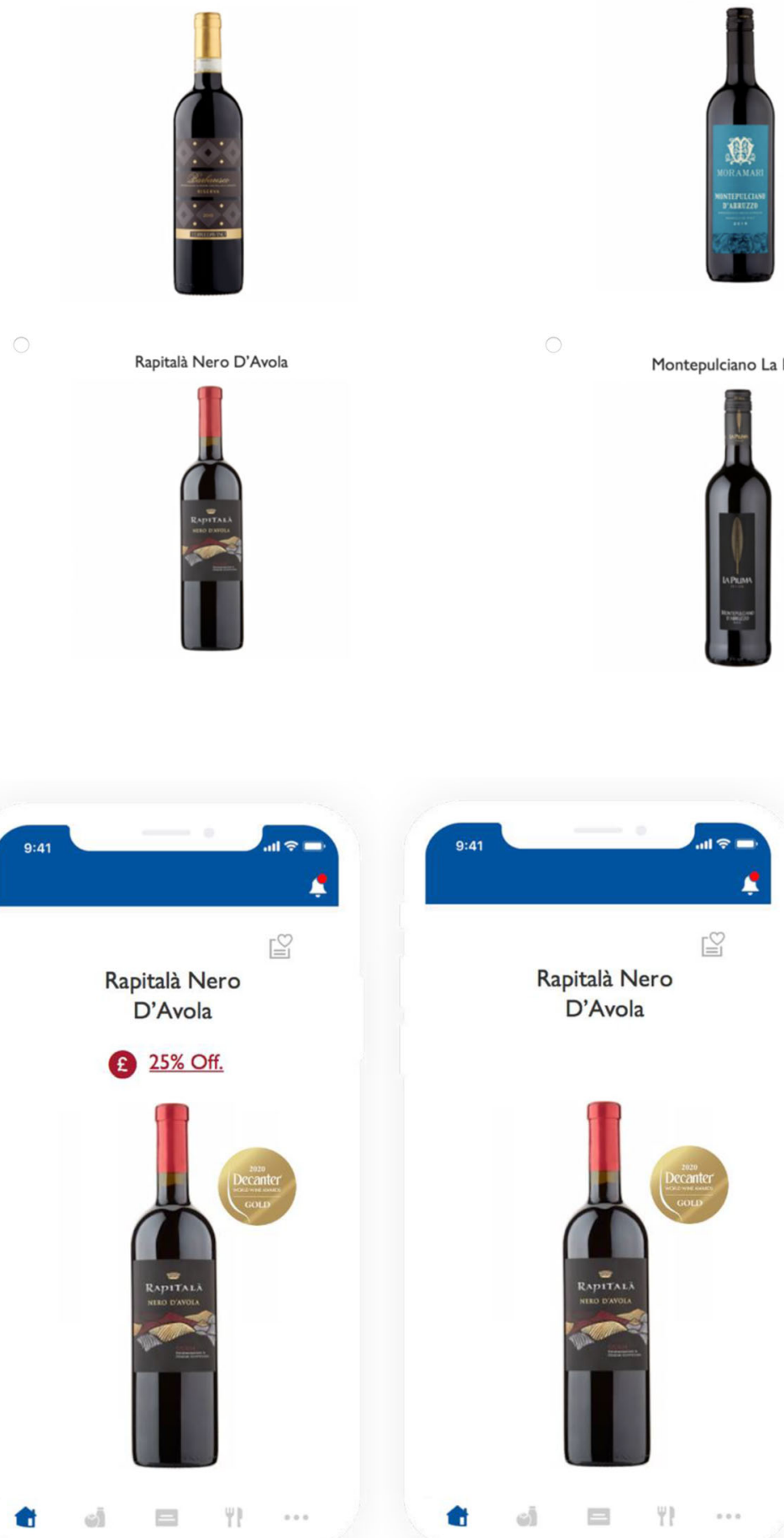

Fig. 9 Location-based ads Study 2, Study 3 price promotion, Study 3 non-price promotion (from left to right) 


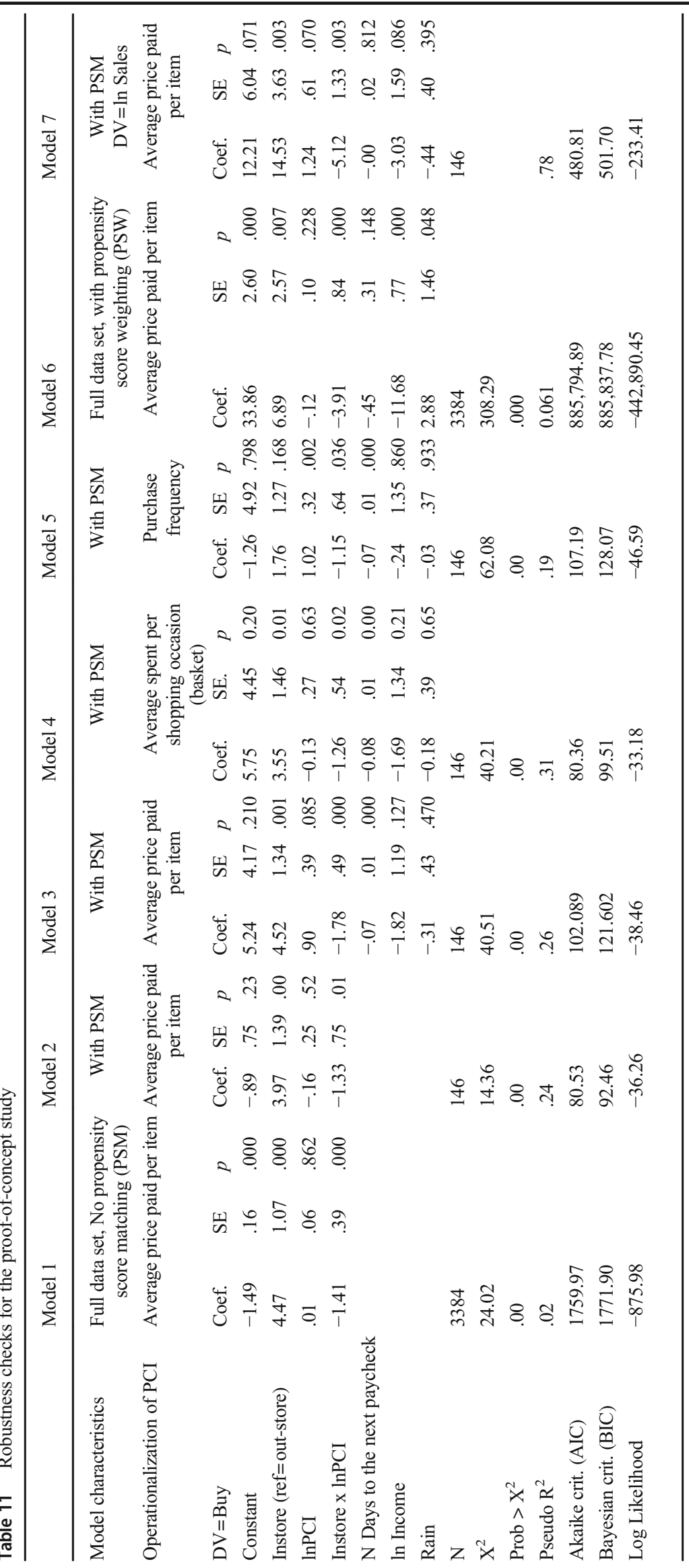


Supplementary Information The online version contains supplementary material available at https://doi.org/10.1007/s11747-021-00784-0.

Acknowledgements We thank Stephanie Immerzeel for her invaluable support in collecting the field data and Nishant Dogra from TBWAINEBOKO for enabling us to conduct the field study. We further would like to thank Peter Cole from X Ingredient and Marnix van Gisbergen for their support in setting up the Virtual Reality Study and Arief Hühn from FreedomLab for his support in designing the field study. We are also thankful for the constructive feedback by the guest editor, editor, and three anonymous reviewers, and the helpful suggestions from participants at the 2019 JAMS Thought Leaders' Conference on Innovating in the Digital Economy.

Open Access This article is licensed under a Creative Commons Attribution 4.0 International License, which permits use, sharing, adaptation, distribution and reproduction in any medium or format, as long as you give appropriate credit to the original author(s) and the source, provide a link to the Creative Commons licence, and indicate if changes were made. The images or other third party material in this article are included in the article's Creative Commons licence, unless indicated otherwise in a credit line to the material. If material is not included in the article's Creative Commons licence and your intended use is not permitted by statutory regulation or exceeds the permitted use, you will need to obtain permission directly from the copyright holder. To view a copy of this licence, visit http://creativecommons.org/licenses/by/4.0/.

\section{References}

Ai, C., \& Norton, E. C. (2003). Interaction terms in logit and probit models. Economics Letters, 80(1), 123-129.

Ailawadi, K. L., Lehmann, D. R., \& Neslin, S. A. (2003). Revenue premium as an outcome measure of brand equity. Journal of Marketing, 67(4), 1-17.

Andrews, M., Luo, X., Fang, Z., \& Ghose, A. (2015). Mobile ad effectiveness: Hyper-contextual targeting with crowdedness. Marketing Science, 35(2), 218-233.

Ataman, M. B., van Heerde, H. J., \& Mela, C. F. (2010). The long-term effect of marketing strategy on brand sales. Journal of Marketing Research, 47(5), 866-882.

Bertini, M., \& Aydinli, A. (2020). Consumer reactance to promotional favors. Journal of Retailing, 96(4), 578-589.

Bleier, A., \& Eisenbeiss, M. (2015a). The importance of trust for personalized online advertising. Journal of Retailing, 91(3), 390-409.

Bleier, A., \& Eisenbeiss, M. (2015b). Personalized online advertising effectiveness: The interplay of what, when, and where. Marketing Science, 34(5), 669-688.

Boerman, S. C., Kruikemeier, S., \& Zuiderveen Borgesius, F. J. (2017). Online behavioral advertising: A literature review and research agenda. Journal of Advertising, 46(3), 363-376.

Brehm, J. W. (1966). A theory of psychological reactance. Academic Press.

Brehm, J. W. (1989). Psychological reactance: Theory and applications. Advances in Consumer Research, 16(1), 72-75.

Bues, M., Steiner, M., Stafflage, M., \& Krafft, M. (2017). How mobile instore advertising influences purchase intention: Value drivers and mediating effects from a consumer perspective. Psychology \& Marketing, 34(2), 157-174.

Chaney, I. M. (2000). External search effort for wine. International Journal of Wine Marketing, 12(2), 5-21.

Chang, C., \& Yen, C. (2013). Missing ingredients in metaphor advertising: The right formula of metaphor type, product type, and need for cognition. Journal of Advertising, 42(1), 80-94.
Cherulnik, P. D., \& Citrin, M. M. (1974). Individual difference in psychological reactance: The interaction between locus of control and mode of elimination of freedom. Journal of Personality and Social Psychology, 29(3), 398-404.

Chung, T. S., Wedel, M., \& Rust, R. T. (2016). Adaptive personalization using social networks. Journal of the Academy of Marketing Science, 44, 66-87.

Coulter, R. A., Price, L. L., \& Feick, L. (2003). Rethinking the origins of involvement and brand commitment: Insights from postsocialist Central Europe. Journal of Consumer Research, 30, 151-169.

Czarny, B.. (2018). How Brands Are Getting More Sophisticated at Using Location Data. Retrieved August 01, 2019 from https:// www.adweek.com/digital/how-brands-are-getting-moresophisticated-at-using-location-data/.

Dahlén, M. (2005). The medium as a contextual cue: Effects of creative media choice. Journal of Advertising, 34(3), 89-98.

Danaher, P. J., Smith, M. S., Ranasinghe, K., \& Danaher, T. S. (2015). Where, when, and how long: Factors that influence the redemption of mobile phone coupons. Journal of Marketing Research, 52(5), 710-725.

Dubé, J. P., Fang, Z., Fong, N., \& Luo, X. (2017). Competitive price targeting with smartphone coupons. Marketing Science, 36(6), 944-975.

Econsultancy (2016). What is location-based advertising \& why is it the next big thing? Retrieved February 21, 2021 from https:// econsultancy.com/what-is-location-based-advertising-why-is-it-thenext-big-thing/.

Edwards, S. M., Li, H., \& Lee, J. (2002). Forced exposure and psychological reactance: Antecedents and consequences of the perceived intrusiveness of pop-up ads. Journal of Advertising, 31(3), 83-95.

eMarketer (2020). US Mobile Ad Spending Update Q3 2020. Retrieved February 21, 2021 from https://www.emarketer.com/content/usmobile-ad-spending-update-q3-2020.

Fang, Z., Gu, B., Luo, X., \& Xu, Y. (2015). Contemporaneous and delayed sales impact of location-based mobile promotions. Information Systems Research, 26(3), 552-564.

Fitzsimons, G. J., \& Lehmann, D. R. (2004). Reactance to recommendations: When unsolicited advice yields contrary responses. Marketing Science, 23(1), 82-94.

Fong, N. M., Fang, Z., \& Luo, X. (2015). Geo-conquesting: Competitive locational targeting of mobile promotions. Journal of Marketing Research, 52(5), 726-735.

Forbes Agency Council (2017). 15 things you should know about location-based advertising. Forbes. Retrieved August 1, 2019 from https://www.forbes.com/sites/forbesagencycouncil/2017/11/22/15things-you-should-know-about-location-based-advertising.

Fujita, K., Eyal, T., Chaiken, S., Trope, Y., \& Liberman, N. (2008). Influencing attitudes toward near and distant objects. Journal of Experimental Social Psychology, 44(3), 562-572.

Gedenk, K., \& Neslin, S. A. (1999). The role of retail promotion in determining future brand loyalty: Its effect on purchase event feedback. Journal of Retailing, 75(4), 433-459.

Ghose, A., Kwon, H. E., Lee, D., \& Oh, W. (2019a). Seizing the commuting moment: Contextual targeting based on mobile transportation apps. Information Systems Research, 30(1), 154-174.

Ghose, A., Li, B., \& Liu, S. (2019b). Mobile targeting using customer trajectory patterns. Management Science, 65(11), 5027-5049.

Google Developers (2020). Choose the optimal radius for your geofence. Retrieved February 21, 2021 from https://developer.android.com/ training/location/geofencing\#choose-the-optimal-radius-for-yourgeofence.

Grewal, D., Bart, Y., Spann, M., \& Zubcsek, P. P. (2016). Mobile advertising: A framework and research agenda. Journal of Interactive Marketing, 34, 3-14.

Grewal, D., Ahlbom, C., Noble, S. M., Shankar, V., Narang, U., \& Nordfält, J. (2020). Mobile integrated kiosks: How communication 
content increases unplanned spending. Working paper, Babson College.

Häubl, G., \& Murray, K. B. (2003). Preference construction and persistence in digital marketplaces: The role of electronic recommendation agents. Journal of Consumer Psychology, 13(1-2), 75-91.

Häubl, G., \& Trifts, V. (2000). Consumer decision making in online shopping environments: The effects of interactive decision aids. Marketing Science, 19(1), 4-21.

Hayes, A. F. (2013). Introduction to mediation, moderation, and conditional process analysis: A regression-based approach. Guilford Press.

Hennig-Thurau, T., Marchand, A., \& Marx, P. (2012). Can automated group recommender systems help consumers make better choices? Journal of Marketing, 76(5), 89-109.

Hochstein, B., Bolander, W., Goldsmith, R., \& Plouffe, C. R. (2019). Adapting influence approaches to informed consumers in highinvolvement purchases: Are salespeople really doomed? Journal of the Academy of Marketing Science, 47(1), 118-137.

Hofacker, C. F., De Ruyter, K., Lurie, N. H., Manchanda, P., \& Donaldson, J. (2016). Gamification and mobile marketing effectiveness. Journal of Interactive Marketing, 34, 25-36.

Hong, S., \& Faedda, S. (1996). Refinement of the Hong psychological reactance scale. Educational and Psychological Measurement, 56(1), 173-182.

Katz, S. J., \& Byrne, S. (2013). Construal level theory of mobile persuasion. Media Psychology, 16(3), 245-271.

Ketelaar, P. E., Bernritter, S. F., van't Riet, J., Hühn, A. E., van Woudenberg, T. J., Müller, B. C., \& Janssen, L. (2017). Disentangling location-based advertising: The effects of location congruency and medium type on consumers' ad attention and brand choice. International Journal of Advertising, 36(2), 356-367.

Ketelaar, P. E., Bernritter, S. F., van Woudenberg, T. J., Rozendaal, E., Konig, R. P., Hühn, A. E., Van Gisbergen, M. S., \& Janssen, L. (2018). "Opening" location-based mobile ads: How openness and location congruency of location-based ads weaken negative effects of intrusiveness on brand choice. Journal of Business Research, 91, 277-285.

Kim, H., Rao, A. R., \& Lee, A. Y. (2008). It's time to vote: The effect of matching message orientation and temporal frame on political persuasion. Journal of Consumer Research, 35(6), 877-889.

Komiak, S. Y., \& Benbasat, I. (2006). The effects of personalization and familiarity on trust and adoption of recommendation agents. MIS Quarterly, 30(4), 941-960.

Laaksonen, P. (1994). Consumer involvement: Concepts and research. Routledge.

Lambrecht, A., \& Tucker, C. (2013). When does retargeting work? Information specificity in online advertising. Journal of Marketing Research, 50(5), 561-576.

Laurent, G., \& Kapferer, J. N. (1985). Measuring consumer involvement profiles. Journal of Marketing Research, 22(1), 41-53.

Li, C., Luo, X., Zhang, C., \& Wang, X. (2017). Sunny, rainy, and cloudy with a chance of mobile promotion effectiveness. Marketing Science, 36(5), 762-779.

Liberman, N., \& Trope, Y. (2008). The psychology of transcending the here and now. Science, 322(5905), 1201-1205.

Luo, X., Andrews, M., Fang, Z., \& Phang, C. W. (2014). Mobile targeting. Management Science, 60(7), 1738-1756.

Marketing Science Institute (2020). Research priorities 2020-2022. Retrieved February 26, 2021 from: https://www.msi.org/articles/ 2020-22-msi-research-priorities-outline-marketers-top-concerns/

MarketingDive (2014). Beacon messages cause drop in app use when overdone: report. Retrieved February 20, 2021 from: https://www. mobilemarketer.com/cms/news/research/18754.html

Mazumdar, T., Raj, S. P., \& Sinha, I. (2005). Reference Price research: Review and propositions. Journal of Marketing, 69, 84-102.
Molitor, D., Spann, M., Ghose, A., \& Reichhart, P. (2020). Effectiveness of location-based advertising and the impact of Interface design. Journal of Management Information Systems, 37(2), 431-456.

Norton, E. C., Wang, H., \& Ai, C. (2004). Computing interaction effects and standard errors in logit and probit models. The Stata Journal, 4(2), 154-167

Nunes, J. C., \& Park, C. W. (2003). Incommensurate resources: Not just more of the same. Journal of Marketing Research, 40(1), 26-38.

Parise, S., Guinan, P. J., \& Kafka, R. (2016). Solving the crisis of immediacy: How digital technology can transform the customer experience. Business Horizons, 59(4), 411-420.

Pearl, J. (2009). Causality: Models, reasoning, and inference. Cambridge: Cambridge University Press.

Petty, R. E., \& Cacioppo, J. T. (1981). Issue involvement as moderator of the effects on attitude of advertising content and context. In K. B. Monroe \& A. Arbor (Eds.), Advances of Consumer Research, Vol. 8 (pp. 20-24). MI: Association for Consumer Research.

Poiesz, T. B. C., \& de Bont, C. J. P. M. (1995). Do we need involvement to understand consumer behavior? In F. R. Kardes \& M. Sujan (Eds.), NA - Advances in Consumer Research Volume 22 (pp. 448-452). Association for Consumer Research.

Pratt, M. (2010). Moderating effects of wine involvement in wine tourism. In 5th international academy of wine business research conference (pp. 8-10). AWBR.

Rothschild, M. L. (1979). Advertising strategies for high and low involvement situations. In J. C. Maloney \& B. Silverman (Eds.), Attitude research plays for high stakes (pp. 74-93). American Marketing Association.

Shankar, V., Kleijnen, M., Ramanathan, S., Rizley, R., Holland, S., \& Morrissey, S. (2016). Mobile shopper marketing: Key issues, current insights, and future research avenues. Journal of Interactive Marketing, 34, 37-48.

Sheng, H., Nah, F. F. H., \& Siau, K. (2008). An experimental study on ubiquitous commerce adoption: Impact of personalization and privacy concerns. Journal of the Association for Information Systems, 9(6), 344-376.

Stiglbauer, B., \& Kovacs, C. (2019). Need for uniqueness determines reactions to web-based personalized advertising. Psychological Reports, 122(1), 246-267.

Summers, C. A., Smith, R. W., \& Reczek, R. W. (2016). An audience of one: Behaviorally targeted ads as implied social labels. Journal of Consumer Research, 43(1), 156-178.

Tong, S., Luo, X., \& Xu, B. (2020). Personalized mobile marketing strategies. Journal of the Academy of Marketing Science, 48(1), 64-78.

Trope, Y., \& Liberman, N. (2010). Construal-level theory of psychological distance. Psychological Review, 117(2), 440-463.

Tsekouras, D., Dellaert, B. G., Donkers, B., \& Häubl, G. (2020). Product set granularity and consumer response to recommendations. Journal of the Academy of Marketing Science, 48(2), 186-202.

Tucker, C. E. (2014). Social networks, personalized advertising, and privacy controls. Journal of Marketing Research, 51(5), 546-562.

Van Doorn, J., \& Hoekstra, J. C. (2013). Customization of online advertising: The role of intrusiveness. Marketing Letters, 24(4), 339-351.

Van't Riet, J., Hühn, A., Ketelaar, P., Khan, V., Konig, R., Rozendaal, E., \& Markopoulos, P. (2016). Investigating the effects of locationbased advertising in the supermarket: Does goal congruence trump location congruence? Journal of Interactive Advertising, 16(1), 3143.

Venkatraman, V., Dimoka, A., Pavlou, P. A., Vo, K., Hampton, W., Bollinger, B., Hershfield, H. E., Ishihara, M., \& Winer, R. S. (2015). Predicting advertising success beyond traditional measures: New insights from neurophysiological methods and market response modeling. Journal of Marketing Research, 52(4), 436-452.

VentureBeat (2018). Why Android Nearby, iBeacons, and Eddystone failed to gain traction. Retrieved February 20, 2021 from: https:// 
venturebeat.com/2018/10/27/why-android-nearby-ibeacons-andeddystone-failed-to-gain-traction/

Wang, F., Zuo, L., Yang, Z., \& Wu, Y. (2019). Mobile searching versus online searching: Differential effects of paid search keywords on direct and indirect sales. Journal of the Academy of Marketing Science, 47(6), 1151-1165.

White, T. B., Zahay, D. L., Thorbjørnsen, H., \& Shavitt, S. (2008). Getting too personal: Reactance to highly personalized email solicitations. Marketing Letters, 19(1), 39-50.
Yost, A. B., Behrend, T. S., Howardson, G., Darrow, J. B., \& Jensen, J. M. (2019). Reactance to electronic surveillance: A test of antecedents and outcomes. Journal of Business and Psychology, 34(1), 7186.

Zaichkowsky, J. L. (1986). Conceptualizing involvement. Journal of Advertising, 15(2), 4-34.

Publisher's note Springer Nature remains neutral with regard to jurisdictional claims in published maps and institutional affiliations. 